\title{
A review of antimicrobial stewardship training in medical education
}

\author{
Sarah L. Silverberg1, Vanessa E. Zannella ${ }^{1}$, Drew Countryman², Ana Patricia Ayala ${ }^{3}$, Erica Lenton ${ }^{3}$, \\ Farah Friesen" ${ }^{4}$ Marcus Law ${ }^{1}$ \\ ${ }^{1}$ Faculty of Medicine, University of Toronto, Toronto, Ontario, Canada \\ ${ }^{2}$ Department of Family and Community Medicine, Faculty of Medicine, University of Toronto, Toronto, Ontario, Canada \\ ${ }^{3}$ Gerstein Science Information Centre, University of Toronto, Toronto, Ontario, Canada \\ ${ }^{4}$ Centre for Faculty Development, Faculty of Medicine, University of Toronto at St. Michael's Hospital, Toronto, Ontario, Canada \\ Correspondence: Marcus Law, Faculty of Medicine, University of Toronto, Medical Sciences Building, 1 King's College Circle, \\ Room 3157, Toronto, ON M5S 1A8, Canada. Email: marcus.law@utoronto.ca
}

Accepted: September 14, 2017

\begin{abstract}
Objectives: We reviewed the published literature on antimicrobial stewardship training in undergraduate and postgraduate medical education to determine which interventions have been implemented, the extent to which they have been evaluated, and to understand which are most effective.

Methods: We searched Ovid MEDLINE and EMBASE from inception to December 2016. Four thousand three hundred eighty-five (4385) articles were identified and underwent title and abstract review. Only those articles that addressed antimicrobial stewardship interventions for medical trainees were included in the final review. We employed Kirkpatrick's four levels of evaluation (reaction, learning, behaviour, results) to categorize intervention evaluations.

Results: Our review included 48 articles. The types of intervention varied widely amongst studies worldwide. Didactic teaching was used heavily in all settings, while student-specific feedback was used primarily in the post-
\end{abstract}

graduate setting. The high-level evaluation was sparse, with 22.9\% reporting a Kirkpatrick Level 3 evaluation; seventeen reported no evaluation. All but one article reported positive results from the intervention. No articles evaluated the impact of an intervention on undergraduate trainees' prescribing behaviour after graduation.

Conclusions: This study enhances our understanding of the extent of antimicrobial stewardship in the context of medical education. While our study demonstrates that medical schools are implementing antimicrobial stewardship interventions, rigorous evaluation of programs to determine whether such efforts are effective is lacking. We encourage more robust evaluation to establish effective, evidence-based approaches to training prescribers in light of the global challenge of antimicrobial resistance.

Keywords: Antimicrobial stewardship, antimicrobial resistance, antibiotic prescribing, undergraduate medical education, postgraduate medical education

\section{Introduction}

Antimicrobial resistance results from a host of factors, including improper antimicrobial prescription, and is an emergent problem. The next generation of physicians must be prepared to face this dilemma as antimicrobial stewardship becomes increasingly vital in the treatment of patients in all fields.

Traditionally, antimicrobial stewardship programs (ASP) have been initiated to address the issue of antimicrobial resistance. Education, as a mainstay feature of these programs, is considered essential to teaching the knowledge necessary for effective stewardship, and can influence physicians' prescribing behaviour. ${ }^{1-3}$ Several educational interventions have been shown to improve antimicrobial prescribing practices and infection control. ${ }^{4-7}$ The majority of antimicrobial stewardship education has involved practicing physicians, specifically targeting prescribing habits with the goal of modifying their approach to antimicrobial prescription. ${ }^{1,8}$ Yet changing the behaviour of practicing physicians has proven difficult. ${ }^{6}$

Few studies have sought to understand the type or efficacy of teaching practices of stewardship principles at the undergraduate and postgraduate medical education levels, particularly at the undergraduate level. ${ }^{9}$ As a result, the literature surrounding how early antimicrobial stewardship 
training starts in a physician's career, and whether teaching these principles from the outset is an effective strategy for combating antimicrobial resistance and lowering overall resistance rates remains unclear. To date, there have been few comprehensive evaluations of antimicrobial stewardship teaching programs and overall effectiveness of these training procedures in undergraduate medical institutions, and those that have been done are geographically restricted. ${ }^{14}$ Accordingly, the extent to which this teaching translates into clinical practice is unclear. While recent studies identify the presence of stewardship curricula, the effectiveness of these interventions remains sparsely evaluated. ${ }^{14-15}$ In light of clinical evidence, it is critical to understand the role that formal learning has to play in teaching prescription habits in order to change such behaviours. Furthermore, an understanding of the effectiveness of such teaching strategies is needed in order to understand its impact, if any, on clinical practice.

Despite the focus of ASP on physician education, antimicrobial prescribing is frequently designated to junior doctors and residents who may not have developed sufficient expertise on antimicrobials. ${ }^{10,16}$ Furthermore, medical students have expressed interest in learning more about antimicrobials and their appropriate usage. ${ }^{11-14,17,18}$ Many students recognize the growing problem of antibiotic overuse, and most would like more training in this area. ${ }^{13-}$ 14,17-19 Students with formal training on antimicrobial stewardship, for example through didactic lectures with infectious disease specialists, feel better prepared for the practice and more comfortable with their knowledge. ${ }^{11}$ However, studies suggest students predominantly have significant gaps in their knowledge regarding appropriate use of antimicrobials. ${ }^{13,16-18,20-24}$ A number of studies have documented efforts of ASP for both undergraduate and postgraduate medical trainees. ${ }^{9,25-28}$ Yet no consensus has been reached as to how to ensure students are invested in antimicrobial stewardship and how to ensure retention of this knowledge and clinical implementation. Teaching appropriate use of antimicrobials varies greatly between countries and programs. ${ }^{9,14,29}$ A greater understanding of how these needs for ASP education are being addressed is an important next step towards addressing rising global awareness of the need for such principles in practice.

Despite student demand for learning on the topic of antimicrobial stewardship, and a focus on antimicrobial stewardship teaching at the physician level, it remains largely unknown at to the level of education at which medical trainees are first exposed to these concepts, how such principles are taught, and to what extent such teaching translates into clinical practice. We examined the published literature from 1946-2016 on antimicrobial stewardship for undergraduate and postgraduate medical trainees, including interventional design, how interventions were evaluated, and the effectiveness of the teaching strategies. We conducted a mapping review with the purpose of organizing what is known surrounding effective teaching on antimicrobial stewardship. ${ }^{30}$ The review focused on the degree to which such interventions were evaluated to be able to make suggestions for further intervention adoption in medical education and to identify future areas of research. Given the heterogeneity of existing ASP research with respect to intervention type and evaluation, such mapping was valuable for examining the flexible implementation of interventions at the curricular level. ${ }^{30}$ Our goal was to better understand the spectrum of teaching strategies employed in educating students on antimicrobial stewardship principles and practices, and to understand how such practices have been evaluated. By exploring this aim, stewardship programs and medical schools can use our findings to implement teaching methods that effectively educate medical students and result in lasting change in the clinical setting, thus helping inform future best practice and curriculum design. Furthermore, by exploring this aim, it is possible to discern trends in education practices, and identify gaps remaining in our understanding of how to educate trainees on antimicrobial stewardship in a way that results in lasting prescribing habits.

\section{Methods}

We conducted a literature review to compile a summary of the current published research on antimicrobial stewardship training in medical education. Ethical approval for this study was not deemed necessary, as our study constitutes a mapping review and did not involve primary data such as patient data collection or analysis. ${ }^{30}$ A systemic map contextualizes a detailed systematic literature review and focuses on key characteristics of the literature, including study population and setting, and is therefore ideal for understanding the nature of ASP educational interventions in terms of trainee group and key intervention characteristics. $^{30,31}$

\section{Search strategy}

We searched Ovid MEDLINE (1946 to 2016) and Ovid EMBASE (1947 to 2016), to identify research, review, and opinion articles addressing antimicrobial stewardship education for undergraduate and postgraduate medical trainees. Search strategies were developed by two authors (APA, EL). The authors translated the search strategies using each database platform's command language and the appropriate search fields. MeSH terms, EMTREE terms, and textwords were used for the search concepts of antibiotics, prescribing patterns, and medical education. The three concepts were combined with a Boolean "AND." No search limits were applied. Articles in English captured in EMBASE and MEDLINE were included in the final searches, which were completed in December 2016. We endeavoured to identify potential studies that were not captured from the database searches, by combing the reference lists of relevant 
studies and reviews included in the full-text review. Grey literature was not included in the search.

\section{Article selection}

Our database searches identified 4385 articles with potential relevance to our study. Three authors (SS, VZ, DC) identified the relevant articles for full-text review by examining the titles and abstracts of the articles identified in the database searches. We included articles written in English that discussed the use of antimicrobial stewardship in medical education. Articles that mentioned solely physician education, continuing education, or public education were excluded. Articles related to non-medical health professions education were also excluded as we focused on medical professionals in this review. Articles that discussed resource management, rational prescribing, or antimicrobials but did not discuss stewardship principles (for example, antimicrobial teaching focused on drug indications and dosing) were also excluded. Lastly, articles that identified only the problem (without discussion of any solution) or articles that did not discuss a specific intervention were excluded. Any disagreements between reviewers were brought to another author (FF), who resolved the dispute. After title and abstract screening, 227 articles were selected for full-text review. After the exclusion criteria were applied, 42 articles satisfied the inclusion criteria (see Figure 1). Searching the reference lists of the 42 included articles identified six additional studies for inclusion, for a total of 48 articles. For a complete list of all included articles, see Appendix.

Each article included for full-text review was independently reviewed by two authors (two of SS, DC, VZ). The authors abstracted the following data fields from the included articles: authors, title, journal, year of publication, location, intervention, purpose of intervention, study design, participants, outcomes, key findings, and the level of evaluation from Kirkpatrick's evaluation of education model:32 (1) reaction (satisfaction or happiness; what participants thought of the educational intervention), (2) learning (change in attitude and/or knowledge or skills gained assessed by test or demonstration), (3) behaviour (transfer of attitude, knowledge and/or skills to workplace or clinical setting, for example, determined through observation), and (4) results (patient care affected or societal impact due to participation in the educational intervention evaluated by looking at patient outcomes, for example).

\section{Results}

Four types of articles were included in this mapping review: (1) commentaries/perspectives encompassing editorials and letters, some of which briefly discussed evaluations that had been done; (2) program descriptions without evaluation or outcomes measured; (3) review articles; and (4) research or evaluation articles with clear study design descriptions and outcomes. Across our dataset, there were nine perspective pieces, ${ }^{25,33-34,39,41,44,47,60,68}$ three program descriptions, ${ }^{28,43,70}$ five review articles, ${ }^{42,45-46,52,71}$ and 31 research articles. ${ }^{9,15-18,24,29,35-}$ $38,40,48-51,53-59,61-67,69$

\section{Target learner group}

Of the 48 articles included in this summary, 14 included only undergraduate medical trainees, ${ }^{9,17,18,24,25,26,33-40} 11$ included both undergraduate and postgraduate trainees, ${ }^{29,41-}$ ${ }^{50} 20$ included only postgraduate trainees, ${ }^{15,16,51-68}$ and three did not specify the training level of the participants (see Table 1). ${ }^{69-71}$ The location of the studies also varied; the majority of studies were situated in Europe (20 studies; $41.7 \%)$, and $16(33.3 \%)$ studies were based in the United Kingdom. Further, eleven articles (22.9\%) took place in North America, three (6.3\%) in Australia, eight (16.7\%) in different Asian countries and two individual studies were conducted in South America and South Africa respectively. Four review articles included articles with geographical diversity.

\section{Intervention design}

The types of interventions varied widely amongst studies and schools. Approaches at the undergraduate level (as demonstrated in detail in Appendix) included didactic teaching, ${ }^{9,25,29,36,40,44,50}$ web-based teaching, ${ }^{39}$ clinical case discussions, ${ }^{35}$ workshops/seminars, ${ }^{26,34,69}$ board games, ${ }^{37-38}$ guideline promotion, ${ }^{35,49-59}$ audits on current stewardship integration in the medical curriculum, ${ }^{17-18,24}$ and intensive modules, ${ }^{47}$ often in combination. Didactic teaching was moderately emphasized on the whole. Studies that examined educational interventions comparatively between medical institutions noted a widespread array of teaching strategies employed. These studies noted an overall inconsistency of trainees' exposure to stewardship topics and of the intervention's emphasis. ${ }^{17-18}$

Interventions aimed at the postgraduate level were similarly varied, and can be explored in Appendix. These studies focused on providing feedback to students in relation to current prescribing practices rather than teaching new skills. Many methods provided resources for residents to consult and use to make prescribing choices and influence behaviours, or focused on identifying gaps in trainees' knowledge and practice with the goal of rectifying their practice in the future. These approaches included: webbased tutorials, ${ }^{47,67}$ workshops, ${ }^{57,62,65-66}$ lectures and information sessions, ${ }^{49,52,58,61-62}$ using a restricted list of antibiotics to promote compliance with guidelines,55,58 audits followed by feedback, ${ }^{15-16,52,56,60,64,67-68}$ chart reviews and feedback, ${ }^{51,58-59,66}$ augmented reality, ${ }^{53}$ viral surveillance program, ${ }^{61}$ using special prescribing pads, ${ }^{54}$ integration of social media platforms such as Twitter and Facebook, ${ }^{67}$ consulting specialists to improve compliance with guidelines, ${ }^{48,52,57,63,66-67}$ and consulting guidelines or written information. ${ }^{44,50,52,56-}$ 57,62,71 Many interventions included a combination of these tactics. Interestingly, we found that auditing techniques evaluating prescribing tendencies was implemented at the 
Table 1. Articles that reported evaluations from each level of Kirkpatrick's evaluation of education model, by intervention target group

\begin{tabular}{|c|c|c|c|c|c|}
\hline $\begin{array}{l}\text { Level of } \\
\text { trainees }\end{array}$ & No evaluation & $\begin{array}{l}\text { Kirkpatrick Level } 1 \\
\text { (Reaction) }\end{array}$ & $\begin{array}{l}\text { Kirkpatrick Level } 2 \\
\text { (Learning) }\end{array}$ & $\begin{array}{l}\text { Kirkpatrick Level } 3 \\
\text { (Behaviour) }\end{array}$ & $\begin{array}{l}\text { Kirkpatrick Level } 4 \\
\text { (Results) }\end{array}$ \\
\hline $\begin{array}{l}\text { Undergraduate } \\
\text { medical } \\
\text { education }\end{array}$ & $\begin{array}{l}\text { Davenport et al. } 2005^{35} \\
\text { Kerr et al. 2001, }{ }^{33} \text { Luther, } \\
\text { Ohl and Hicks } 2013,{ }^{25} \\
\text { Pulcini et al. 2015, } \\
\text { Shankar et al. } 2011,{ }^{26} \\
\text { Wright and Jain } 2004^{34}\end{array}$ & $\begin{array}{l}\text { Beylefeld and Struwig } \\
2007,{ }^{38} \text { Chuenchom, et al. } \\
2016,{ }^{17} \text { Haque et al. } \\
2016,{ }^{18} \text { Hoque, Mostafa } \\
\text { \& Haque, 2016, }{ }^{24} \\
\text { Marwick and Nathwani } \\
2007,{ }^{39} \text { Minen et al. } \\
2010,{ }^{36} \text { Valente et al. } \\
2009^{37}\end{array}$ & $\begin{array}{l}\text { Huang et al. } 2013,{ }^{40} \\
\text { Marwick and Nathwani, } \\
2007,39 \text { Valente et al. } \\
2009^{37}\end{array}$ & & \\
\hline $\begin{array}{l}\text { Postgraduate } \\
\text { medical } \\
\text { education }\end{array}$ & $\begin{array}{l}\text { Brennan and Mattick } \\
2013,{ }^{52} \text { Philp, Wilford and } \\
\text { Low } 1986^{51}\end{array}$ & $\begin{array}{l}\text { Bannan et al. 2009, }{ }^{5 b} \\
\text { Gharbi et al. 2016, }{ }^{16} \\
\text { Nifakos, Tomson and } \\
\text { Zary } 2014{ }^{53} \text { Nand et al. } \\
2016,{ }^{68} \text { Temte et al. } \\
1999{ }^{61} \text { Welch et al. } \\
2000^{54}\end{array}$ & $\begin{array}{l}\text { Faryna, Wegowske and } \\
\text { Goldenberg } 1987,{ }^{56} \\
\text { Feucht et al. 2003, }{ }^{57} \text { Ikai } \\
\text { et al. 2012, } \\
\text { Pisano et al. 2016, }{ }^{67} \\
\text { Rawson et al. 2016 }{ }^{15}\end{array}$ & $\begin{array}{l}\text { Légaré et al } 2011,{ }^{\text {by }} \text { Irfan } \\
\text { et al. } 2015,{ }^{65} \text { Main and } \\
\text { Koerner } 2012,{ }^{60} \text { McLellan } \\
\text { et al. } 2016,{ }^{66} \text { Temte et al. } \\
\text { 1999, }{ }^{61} \text { Welch et al. } \\
\text { 2000, }{ }^{54} \text { Zwar, Gordon and } \\
\text { Sanson-Fisher } 1995,{ }^{62} \\
\text { Zwar et al. } 1999,{ }^{63} \text { Lee et } \\
\text { al. } 2014^{64}\end{array}$ & \\
\hline $\begin{array}{l}\text { Mixed under- } \\
\text { graduate and } \\
\text { postgraduate } \\
\text { medical } \\
\text { education }\end{array}$ & $\begin{array}{l}\text { Davey et al } 1993,{ }^{29} \\
\text { Ghafur } 2013,{ }^{41} \text { Green- } \\
\text { wood } 1998,{ }^{44} \text { Lee et al. } \\
2013,{ }^{45} \text { Lee et al. } 2015,{ }^{46} \\
\text { McNulty, Cookson and } \\
\text { Lewis } 2012,{ }^{43} \text { Pulcini and } \\
\text { Gyssens } 2013^{42}\end{array}$ & & $\begin{array}{l}\text { Dawson, Bennett and } \\
\text { Ongley, 2010, }{ }^{47} \text { Zamin, } \\
\text { Pitre and Conly, } 1997^{48}\end{array}$ & $\begin{array}{l}\text { De Souza et al. } 2006,{ }^{\text {bu }} \\
\text { Thamlikitkul et al. } 1998^{49}\end{array}$ & $\begin{array}{l}\text { Thamlikitkul et al. } \\
1998^{49}\end{array}$ \\
\hline Unspecified & $\begin{array}{l}\text { Davey et al. } 2007,{ }^{\prime 1} \mathrm{Le} \\
\text { Normand et al. } 1994^{69}\end{array}$ & & Bain $1984^{\prime \prime}$ & & \\
\hline
\end{tabular}

Table 2. Types of Interventions and their Kirkpatrick Level of Evaluation ${ }^{* \dagger}$

\begin{tabular}{|c|c|c|c|c|c|}
\hline Level of trainees & No Evaluation & Kirkpatrick Level 1 & Kirkpatrick Level 2 & Kirkpatrick Level 3 & Kirkpatrick Level 4 \\
\hline Undergraduate & $\begin{array}{l}\text { Didactic teaching (4) } \\
\text { Workshop/seminar (3) } \\
\text { Clinical case discussion (1) } \\
\text { Guideline promotion (1) }\end{array}$ & $\begin{array}{l}\text { Didactic teaching (1) } \\
\text { Board game (1) } \\
\text { Audit (3) }\end{array}$ & $\begin{array}{l}\text { Didactic teaching (1) } \\
\text { Web-based teaching (1) } \\
\text { Board game (1) } \\
\text { Intensive module (1) }\end{array}$ & $\begin{array}{l}\text { Guideline promotion } \\
(2) \\
\text { Didactic teaching (1) }\end{array}$ & \\
\hline Postgraduate & $\begin{array}{l}\text { Specialist consult (3) } \\
\text { Guideline use (2) } \\
\text { Didactic teaching (1) } \\
\text { Audit (1) } \\
\text { Chart review (1) }\end{array}$ & $\begin{array}{l}\text { Restricted antibiotic } \\
\text { list (1) } \\
\text { Augmented reality (1) } \\
\text { Audit (2) }\end{array}$ & $\begin{array}{l}\text { Guideline use (2) } \\
\text { Specialist consult (3) } \\
\text { Web-based teaching (2) } \\
\text { Workshops (1) } \\
\text { Didactic teaching (1) Chart } \\
\text { review (1) } \\
\text { Restricted antibiotic list (1) } \\
\text { Audit (3) } \\
\text { Social media \& online } \\
\text { education (1) }\end{array}$ & $\begin{array}{l}\text { Didactic teaching (2) } \\
\text { Audit (2) } \\
\text { Guideline use (3) } \\
\text { Specialized prescribing } \\
\text { pads (1) } \\
\text { Viral surveillance } \\
\text { program (1) } \\
\text { Specialist consult (3) } \\
\text { Chart Review (3) } \\
\text { Workshops (3) }\end{array}$ & Didactic teaching (1) \\
\hline
\end{tabular}

Numbers reflect the number of different studies employing each intervention type

${ }^{\dagger}$ Some studies used more than one type of intervention, or the same intervention in both undergraduate and postgraduate students, but specific interventions are listed separately

postgraduate level, but not in undergraduate medical education settings.

\section{Outcomes (variables of interest)}

Studies measured a wide variety of outcomes (see Appendix for full list of variables of interest). Although it was clear from the studies included in this review that medical students required supplementary antimicrobial education and desired their curricula to be augmented, all but one of the articles that measured outcomes (Kirkpatrick's Levels 14) reported that the intervention made a difference. Notably, one exception we identified was an article by De Souza et al., which evaluated the current medical curricula from an ASP perspective, but did not involve a more specifically active intervention. ${ }^{50}$ Additionally, all studies that evaluated outcomes on a Kirkpatrick Level 1 scale supported sentiments echoed in the literature that, despite resources available in hospital or knowledge gained through the intervention, trainees do not feel comfortable with their knowledge. In studies evaluating behavioural change (Kirkpatrick Level 3-4), most outcomes included rates of prescriptions (total and/or inappropriate prescriptions), and fewer directly evaluated patient safety or cost parameters. In studies that evaluated knowledge (Kirkpatrick Level 2), 
Records identified $(4,385)$

- Ovid MEDLINE in-process \& other nonindexed citations $(2,018)$

- Ovid EMBASE Classic \& EMBASE $(2,367)$

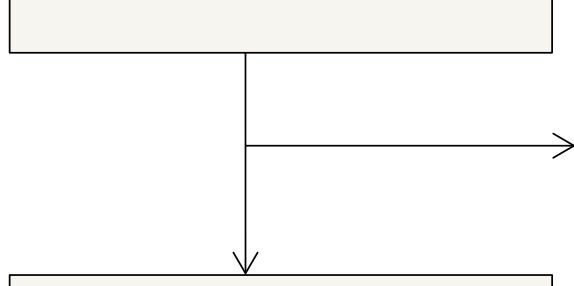

Titles and abstracts reviewed $(4,013)$

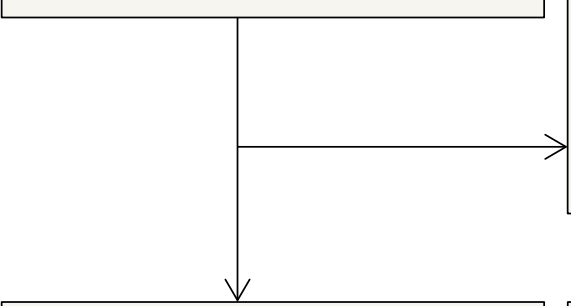

Articles included in full-text review (228)

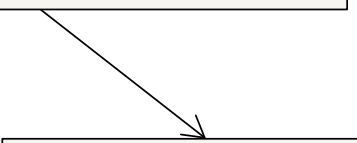

Full-text articles retrieved and reviewed (234)

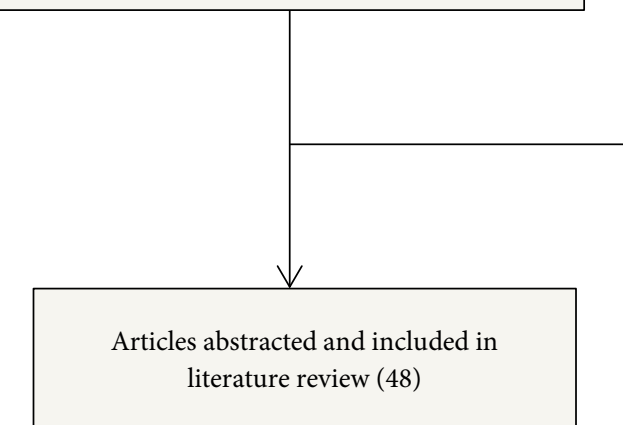

Duplicates removed (123)

- MEDLINE (64)

- EMBASE (59)

Articles not in English removed (249)

- MEDLINE (153)

- EMBASE (96)

Articles removed on the basis of title/abstract review $(3,785)$

- Only mentioned physician education, continuing education, or public education

- Discussed interventions in non-medical health professions

Articles included in full-text review from reference list searches (6)

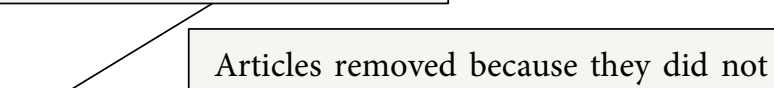
meet inclusion criteria (186)

- Only mentioned physician education, continuing education, or public education

- Discussed interventions in non-medical health professions

- Discussed resource management, rational prescribing, or antimicrobials but not antimicrobial stewardship specifically

- Did not discuss a specific intervention, e.g. knowledge evaluations that do not mention the type of learning students had, or attitudes of students regarding antibiotics

- Identified the problem without discussing any solution

Figure 1. Search Strategy Flow Chart 
there was variability between those evaluating students' knowledge of stewardship principles and those evaluating the application of such principles to sample cases in a controlled setting.

\section{Evaluations}

Over half $(n=31,64.6 \%)$ of the 48 studies included in this review reported that interventions were evaluated in some capacity. Eleven (22.9\%) articles reported on a Kirkpatrick Level 3 or 4 (behaviour) evaluation of the intervention, ${ }^{49-}$ 50,54,59-66 eleven (22.9\%) reported on a knowledge evaluation (Kirkpatrick Level 2), ${ }^{15,37,39-40,47-48,56-58,67,70}$ nine (18.8\%) reported only an evaluation of participants' reactions (Kirkpatrick Level 1), ${ }^{16-18,24,36,38,53,55,68}$ and 17 (35.4\%) reported no evaluation of the intervention at all. ${ }^{9,25,26,29,33-35,41-46,51-52,69,71}$ Of those evaluating behaviour, no articles reported long-term behaviour changes after the intervention was completed, as only pre- and post-intervention evaluations were conducted. Of interventions that were evaluated, a mix between summative and mixed summative/formative evaluations was conducted. None of the articles that targeted undergraduate medical students evaluated whether the intervention influenced their prescribing behaviour either as a senior medical student or followed them beyond graduation (see Table 1). No undergraduate evaluations were followed up by further postgraduate evaluations, and no undergraduate articles examined the longitudinal effect of the measured intervention on future practice.

Additionally, more individualized teaching methods, such as audits, consults, and chart reviews were more frequently evaluated at a higher Kirkpatrick level, while workshops and didactic teaching, interventions that often occurred in larger groups rather than one-on-one, were generally not evaluated at a high level (see Table 2).

\section{Discussion}

In this review, we found a myriad of training approaches to antimicrobial stewardship in undergraduate and postgraduate medical education. While our understanding of antimicrobial resistance has grown, our understanding of effective educational approaches on the topic has not. Approximately one quarter of educational interventions evaluated behaviour change (Kirkpatrick Level 3), and of these, only two articles that included undergraduate education evaluated interventions at this level. Further, studies frequently did not proceed to evaluate interventions at all. There continues to be a dearth of information available as to whether the effects measured by the studies that did evaluate their outcomes last beyond the immediate intervention time frame. The long-term effects of these educational interventions are unknown as the studies we identified largely do not include follow-up. It remains unclear whether these identified interventions are effective, more broadly, at influencing physician behaviour. In order to change the prescribing habits of future physicians and to lower antimi- crobial resistance rates by teaching trainees best practices, more robust evaluations of innovative teaching strategies are needed. Many studies included in this review $(n=17)$, did not evaluate the teaching strategies employed by respective investigators; instead, they simply reported on implementation. Evidence-based curriculum development is integral in the facilitation of best clinical practices. Medical educators and researchers must rigorously evaluate the efficacy of new educational interventions. ${ }^{72}$ Particularly in the undergraduate medical setting, it is invaluable to understand whether teaching about appropriate use of antimicrobials is retained by students as they go out to practice. We must understand whether interventions can be effectively applied at this level to influence prescribing behaviour on a long-term basis (i.e., Kirkpatrick Level 3), which will be instrumental in facilitating better patient care and societal impacts collectively (i.e., Kirkpatrick Level 4).

With antimicrobial resistance a growing global concern, there have been calls for further integration of teaching on this topic at the undergraduate medical level. ${ }^{42}$ Pulcini et al. identified physicians' lack of knowledge of infectious diseases and antibiotics as a cause of their inappropriate prescribing, ${ }^{28}$ and both Pulcini et al. and Davey et al. recommended the translation of prescribing principles into learning topics and competencies for undergraduate core curricula. $^{29,42}$ Our results support the findings of the Infectious Diseases Society of America that education on appropriate antimicrobial prescribing is highly variable across training facilities in the United States. ${ }^{73}$ In addition, similar inconsistencies in training seen on a global scale. Several recent studies conducted in the United Kingdom show that educational standards concerning antimicrobial stewardship vary greatly between postgraduate curricula, and provide further evidence that such inconsistent standards are a problem globally. ${ }^{73}$ To identify which of these educational interventions is most effective in bolstering medical student's antimicrobial knowledge, our study shows that further evaluations of current approaches are needed. Once effective training programs are identified, such programs should then be expanded across undergraduate medical curricula. Recent changes to the Leader role in the CanMEDS 2015 physician competency framework, emphasizing quality improvement and patient safety ${ }^{74}$ align with the appraisal of antimicrobial stewardship required at the undergraduate level. CanMEDS is a framework that outlines requisite competencies physicians need to successfully enact in order to meet the health care needs of the individuals and groups they serve. One of the competencies of the Leader role is that a physician must "engage in the stewardship of health care resources" ${ }^{74}$ With this objective in mind, developing antimicrobial resistance education at the undergraduate level and evaluating such strategies to better educate future physicians fits well with the CanMEDS framework.

The educational interventions included in this review were highly varied, and different interventions were often 
used in different combinations. This practice of trying various strategies reflects the directive, led by Julio Frenk and Lincoln Chen, necessitating transformative and creative teaching initiatives. ${ }^{75}$ However, the included articles also span many decades and demonstrate little forward momentum towards improving and implementing ideas that have been shown to be promising in the past. While there is a great need for innovation and for the development of new ideas, there is no need to re-invent the wheel. More research must be executed to build on existing interventions and design effective learning programs. Collaboration between medical schools and the breakdown of institutional barriers (i.e. sharing best educational practices) can help accelerate this development process. Sharing resources and learning across institutions, as described by Frenk et al., ${ }^{75}$ is integral to moving forward, but it also requires stringent evaluation metrics to assess collaborations and new educational interventions.

Finally, it remains unclear as to the extent that antimicrobial stewardship is actually incorporated into undergraduate medical curricula, particularly in different settings globally. Future research should target the extent and nature of these stewardship programs and must evaluate their overall effectiveness.

Due to the nature of our study, there are certain limitations to the interpretation of our results. Our review discusses the available English-language published literature, and does not capture studies that have been exclusively published in other languages. Thus, our findings might reflect the stewardship practices of the English-speaking world more heavily. However, considering the geographical diversity in the included studies, our findings are likely generalizable (on an international scale). In addition, we conducted our literature search through peer-reviewed journal articles indexed in two databases, excluding other databases. Other program descriptions and practices existing outside of peer-reviewed journal articles (e.g., grey literature or book chapters) were not included in this review; these bodies of literature are unlikely to include evaluations of antimicrobial stewardship interventions and were deemed outside of this study's scope. However, the exclusion of grey literature from this review may limit our understanding of global trends due to the lack of published evaluation of such medical curricula. Finally, our review focused entirely on medical prescribers at the trainee level, and therefore the role of other health care professionals in antimicrobial stewardship practices was not included. These allied health professionals play a significant role in antimicrobial stewardship, particularly in jurisdictions where autonomous prescribing capabilities are authorized. However, comparing medical training with other health professional fields, and evaluating stewardship training in each profession's curricula, are difficult to compare due to their vastly different structure and outside this study's scope.

\section{Conclusions}

Although our understanding of the scope of antimicrobial resistance has progressed, our understanding of which educational approaches to antimicrobial stewardship are effective has not. As physicians strive towards evidenceinformed education, we need an evidence base that captures the impact of such programs on trainees' prescribing behaviour after graduation. Currently, there are no best practice or national guidelines for teaching antimicrobial stewardship in undergraduate and postgraduate medical education. However, our study demonstrates that medical schools worldwide are supporting multitudinous antimicrobial stewardship interventions. It is possible that many intervention designs result in the desired outcome, simply by trainees' attention to this area of interest. If so, there is an opportunity to optimize learning outcomes and intervention efficiency. Yet if such gains are short-lived and not habit forming, we must return to the drawing board to once again target prescribing habits in a new manner. Are we wasting resources and supporting ineffective interventions that are not cost-effective? Are we wasting time and trusting that these interventions will lead to a future culture of stewardship? Further rigorous evaluation of existing programs that capture Kirkpatrick Levels 3 and 4 are necessary to answer these questions, and thereby encourage additional medical education programs to incorporate such practices into their curricula. In order to foster a culture of stewardship amongst our trainees, we must develop and assess proficient educational interventions.

\section{Conflict of Interest}

The authors declare that they have no conflict of interest.

\section{References}

1. Dellit TH, Owens RC, McGowan JE, Gerding DN, Weinstein RA, Burke JP, et al. Infectious diseases society of America and the society for healthcare epidemiology of America guidelines for developing an institutional program to enhance antimicrobial stewardship. Clin Infect Dis. 2007;44:159-177. 2. Costelloe C, Metcalfe C, Lovering A, Mant D, Hay AD. Effect of antibiotic prescribing in primary care on antimicrobial resistance in individual patients: systematic review and meta-analysis. BMJ. 2010;340:c2096.

3. De Santis G, Harvey KJ, Howard D, Mashford ML, Moulds RF. Improving the quality of antibiotic prescription patterns in general practice. The role of educational intervention. Med J Aust. 1994;160:502-505.

4. Cooper BS, Stone SP, Kibbler CC, Cookson BD, Roberts JA, Medley GF et al. Systematic review of isolation policies in the hospital management of methicillin-resistant Staphylococcus aureus: a review of the literature with epidemiological and economic modelling. Health Technol Assess. 2003;7:1194.

5. Cooper BS, Stone SP, Kibbler CC, Cookson BD, Roberts JA, Medley GF, et al. Isolation measures in the hospital management of methicillin resistant Staphylococcus aureus (MRSA): systematic review of the literature. BMJ. 2004;329:533

6. Davey P, Brown E, Charani E, Fenelon L, Gould IM, Holmes A, et al. Interventions to improve antibiotic prescribing practices for hospital inpatients. Cochrane Database Syst Rev. 2013;4:CD003543.

7. Davey P, Brown E, Fenelon L, Finch R, Gould I, Holmes A, et al Systematic review of antimicrobial drug prescribing in hospitals. Emerg Infect Dis. 2006;12:211-216. 
8. Roumie CL, Halasa NB, Edwards KM, Zhu Y, Dittus RS, Griffin MR. Differences in antibiotic prescribing among physicians, residents, and nonphysician clinicians. Am J Med. 2005;118:641-648.

9. Pulcini C, Wencker F, Frimodt-Møller N, Kern WV, Nathwani D, Rodriguez-Baño J, et al. European survey on principles of prudent antibiotic prescribing teaching in undergraduate students. Clin Microbiol Infect. 2015;21(4):354-361.

10. Charani E, Cooke J, Holmes A. Antibiotic stewardship programmeswhat's missing? J Antimicrob Chemother. 2010;65:2275-2277.

11. Abbo LM, Cosgrove SE, Pottinger PS, Pereyra M, Sinkowitz-Cochran $\mathrm{R}$, Srinivasan A, et al. Medical students' perceptions and knowledge about antimicrobial stewardship: how are we educating our future prescribers? Clin Infect Dis. 2013;57(5):631-638.

12. Pulcini C, Williams F, Molinari N, Davey P, Nathwani D. Junior doctors' knowledge and perceptions of antibiotic resistance and prescribing: a survey in France and Scotland. Clin Microbiol Infect. 2011;17(1):80-87.

13. Dyar OJ, Howard P, Nathwani D, Pulcini C. Knowledge, attitudes, and beliefs of French medical students about antibiotic prescribing and resistance. Med Maladies Infect. 2013;43(10):423-430.

14. Castro-Sánchez E, Drumright LN, Gharbi M, Farrell S, Holmes AH. Mapping Antimicrobial Stewardship in Undergraduate Medical, Dental, Pharmacy, Nursing and Veterinary Education in the United Kingdom. PloS One. 2016;11(2):e0150056.

15. Rawson TM, Butters TP, Moore LS, Castro-Sánchez E, Cooke FJ, Holmes AH. Exploring the coverage of antimicrobial stewardship across UK clinical postgraduate training curricula. J Antimicrob Chemother. 2016;71(11):3284-3292.

16. Gharbi M, Moore LS, Castro-Sánchez E, Spanoudaki E, Grady C, Holmes $\mathrm{AH}$, et al. A needs assessment study for optimizing prescribing practice in secondary care junior doctors: The Antibiotic Prescribing Education among Doctors (APED). BMC Infect Dis. 2016;16(1):456.

17. Chuenchom N, Thamlikitkul V, Chaiwarith R, Deoisares R, Rattanaumpawan $\mathrm{P}$. Perception, attitude and knowledge regarding antimicrobial resistance, appropriate antimicrobial use and infection control among future medical practitioners: A multicenter study. Infect Control Hosp Epidemiol. 2016;37(5):603-605.

18. Haque M, Rahman NI, Zulkifli Z, Ismail S. Antibiotic prescribing and resistance: Knowledge level of medical students of clinical years of university Sultan Zainal Abidin, Malaysia. Ther Clin Risk Manag. 2016;12:413-426.

19. Ibia E, Sheridan M, Schwartz R. Knowledge of the principles of judicious antibiotic use for upper respiratory infections: a survey of senior medical students. South Med J. 2005;98(9):889-896.

20. Dyar OJ, Pulcini C, Howard P, Nathwani D. European medical students: a first multicentre study of knowledge, attitudes and perceptions of antibiotic prescribing and antibiotic resistance. J Antimicrob Chemother. 2014;69:842-846.

21. Humphreys H, Dillane T, O'Connell B, Luke LC. Survey of recent medical graduates' knowledge and understanding of the treatment and prevention of infection. Irish Med J. 2006;99(2):58-59.

22. Jamshed SQ, Elkalmi R, Rajiah K, Al-Shami AK, Shamsudin SH, Siddiqui MJ, et al. Understanding of antibiotic use and resistance among final-year pharmacy and medical students: a pilot study. J Infect Dev Ctries. 2014;8(6):780-785

23. Khan A K A, Banu G, K K R. Antibiotic Resistance and Usage-A Survey on the Knowledge, Attitude, Perceptions and Practices among the Medical Students of a Southern Indian Teaching Hospital. J Clin Diagn Res. 2013; 7(8):1613-6.

24. Hoque R, Mostafa A, Haque M. Insight of medical students of clinical years to antimicrobials prescribing and resistance in private medical school, Chittagong, Bangladesh. Journal of Young Pharmacists. 2016; 8(4):447-455.

25. Luther VP, Ohl CA, Hicks LA. Antimicrobial stewardship education for medical students. Clin Infect Dis. 2013;57(9):1366.

26. Shankar PR, Bajracharya O, Jha N, Gurung SB, Singh KK. Teaching medical students to use antibiotics rationally in a medical school in Nepal. Edu Med J. 2011;2(10):WMC002329.

27. D Walker, T Fowler, editors. Annual report of the Chief Medical Officer. Volume 2. Infections and the rise of antimicrobial resistance. Department of Health; 2011 [cited 14 Oct 2017]; Available from:
http://media.dh.gov.uk/network/357/files/2013/03/CMO-Annual-ReportVolume-2-20111.pdf.

28. Moody J, Cosgrove SE, Olmsted R, Septimus E, Aureden K, Oriola S, et al. Antimicrobial stewardship: a collaborative partnership between infection preventionists and healthcare epidemiologists. Infect Control Hosp Epidemiol. 2012;33:328-330.

29. Davey P, Hudson S, Ridgway G, Reeves D. A survey of undergraduate and continuing medical education about antimicrobial chemotherapy in the United Kingdom. British society of antimicrobial chemotherapy working party on antimicrobial use. Br J Clin Pharmacol. 1993;36:511-9.

30. Grant MJ, Booth A. A typology of reviews: an analy-sis of 14 review types and associated methodologies. Health Info Libr J. 2009; 26(2):91-108. 31. Cooper ID. What is a "mapping study?" J Med Libr Assoc. 2016;104(1), 76-78.

32. Kirkpatrick DL. Evaluation of training. In: Craig R, Bittel I, editors. Training and Development Handbook. First edition. New York: McGrawHill; 1967.

33. Kerr KG, Ottery C, Hawkey PM, Roberts TE. The teaching of appropriate use of antimicrobials. Lancet. 2001;358(9299):2173-2174.

34. Wright EP, Jain P. Survey of antibiotic knowledge amongst final year medical students. J Antimicrob Chemother. 2004;53(3):550-551.

35. Davenport LA, Davey PG, Ker JS, BSAC Undergraduate Education Working Party. An outcome-based approach for teaching prudent antimicrobial prescribing to undergraduate medical students: report of a Working Party of the British Society for Antimicrobial Chemotherapy. J Antimicrob Chemother. 2005; 56(1):196-203.

36. Minen MT, Duquaine D, Marx MA, Weiss D. A survey of knowledge, attitudes, and beliefs of medical students concerning antimicrobial use and resistance. Microb Drug Resist. 2010;16(4):285-9.

37. Valente P, Lora PS, Landell MF, Schiefelbein CS, Girardi FM, Souza Ldos R, et al. A game for teaching antimicrobial mechanisms of action. Med Teach. 2009;31(9):e383-392.

38. Beylefeld AA, Struwig MC. A gaming approach to learning medical microbiology: students' experiences of flow. Med Teach. 2007;29(9):933-40. 39. Marwick CA, Nathwani D. Improving antimicrobial prescribing through knowledge and skills. J Antimicrob Chemother. 2007;59(4):819-20.

40. Huang Y, Gu J, Zhang M, Ren Z, Yang W, Chen Y, et al. Knowledge, attitude and practice of antibiotics: a questionnaire study among 2500 Chinese students. BMC Med Educ. 2013;13(1):1.

41. Ghafur A. India must overhaul medical training to act on antimicrobial resistance. BMJ. 2013;347:f4230.

42. Pulcini C, Gyssens IC. How to educate prescribers in antimicrobial stewardship practices. Virulence. 2013;4(2):192-202.

43. McNulty CA, Cookson BD, Lewis MA. Education of healthcare professionals and the public. J Antimicrob Chemother. 2012; 67 Suppl 1:i118.

44. Greenwood D. Resistance to antimicrobial agents: a personal view. J Med Microbiol. 1998;47(9):751-755.

45. Lee CR, Cho IH, Jeong BC, Lee SH. Strategies to minimize antibiotic resistance. Int J Environ Res Pub Heal. 2013;10(9):4274-4305.

46. Lee CR, Lee JH, Kang LW, Jeong BC, Lee SH. Educational effectiveness, target, and content for prudent antibiotic use. Biomed Res Int. 2015;2015:214021

47. Dawson SJ, Bennett H, Ongley V. E-learning module for delivering infection prevention and control training. J Hosp Infect. 2010;76(1):89-90.

48. Zamin MT, Pitre MM, Conly JM. Development of an intravenous-tooral route conversion program for antimicrobial therapy at a Canadian tertiary care health facility. Ann Pharmacother. 1997;31(5):564-570.

49. Thamlikitkul V, Danchaivijitr S, Kongpattanakul S, Ckokloikaew S. Impact of an educational program on antibiotic use in a tertiary care hospital in a developing country. J Clin Epidemiol. 1998;51(9):773-778.

50. De Souza V, MacFarlane A, Murphy AW, Hanahoe B, Barber A, Cormican M. A qualitative study of factors influencing antimicrobial prescribing by non-consultant hospital doctors. J Antimicrob Chemother. 2006;58(4):840-843.

51. Philp JR, Wilford RJ, Low IW. Implications for medical education of nonrational prescribing by residents. Acad Med 1986;61(5):418-420.

52. Brennan N, Mattick K. A systematic review of educational interventions to change behaviour of prescribers in hospital settings, with a particular emphasis on new prescribers. Brit J Clin Pharmaco. 2013;75(2):359-372. 
53. Nifakos S, Tomson T, Zary N. Combining physical and virtual contexts through augmented reality: design and evaluation of a prototype using a drug box as a marker for antibiotic training. PeerJ. 2014;2:e697.

54. Welch SA, Novy M, Preisz P, Quinn DI, Whicker SD, Brown SE, et al. Promoting rational prescribing by emergency department junior medical officers. Aust J Hosp Pharm. 2000;30(6):262-267.

55. Bannan A, Buono E, McLaws ML, Gottlieb T. A survey of medical staff attitudes to an antibiotic approval and stewardship programme. Intern Med J. 2009;39(10):662-668.

56. Faryna A, Wergowske GL, Goldenberg K. Impact of therapeutic guidelines on antibiotic use by residents in primary care clinics. J Gen Intern Med. 1987;2(2):102-107.

57. Feucht CL, Rice LB. An interventional program to improve antibiotic use. Ann Pharmacother. 2003;37(5):646-651.

58.Ikai H, Morimoto T, Shimbo T, Imanaka Y, Koike K. Impact of postgraduate education on physician practice for community-acquired pneumonia. J Eval Clin Pract. 2012;18(2):389-395.

59.Légaré F, Labrecque M, Godin G, LeBlanc A, Laurier C, Grimshaw J, et al. Training family physicians and residents in family medicine in shared decision making to improve clinical decisions regarding the use of antibiotics for acute respiratory infections: protocol for a clustered randomized controlled trial. BMC Fam Pract. 2011;12:3.

60.Main B, Koerner RJ. The medical educators' contribution to curtailing antimicrobial resistance. J Grad Med Ed. 2012;4(3):392.

61. Temte JL, Shult PA, Kirk CJ, Amspaugh J. Effects of viral respiratory disease education and surveillance on antibiotic prescribing. Fam Med. 1999;31:101-106.

62.Zwar NA, Gordon JJ, Sanson-Fisher RW. Evaluation of an educational program in rational prescribing for GP trainees. Aust Fam Physician. 1995;24(5):833-838.

63. Zwar N, Wolk J, Gordon J, Sanson-Fisher R, Kehoe L. Influencing antibiotic prescribing in general practice: a trial of prescriber feedback and management guidelines. Fam Pract. 1999;16(5):495-500.

64. Lee TC, Frenette C, Jayaraman D, Green L, Pilote L. Antibiotic selfstewardship: trainee-led structured antibiotic time-outs to improve antimicrobial use. Ann Intern Med. 2014; 161 Suppl 10:S53-8.
65. Irfan N, Brooks A, Mithoowani S, Celetti SJ, Main C, Mertz D. et al. A controlled quasi-experimental study of an educational intervention to reduce the unnecessary use of antimicrobials for asymptomatic bacteriuria. PLoS One. 2015;10(7):e0132071.

66. McLellan L, Dornan T, Newton P, Williams SD, Lewis P, Steinke D, et al. Pharmacist-led feedback workshops increase appropriate prescribing of antimicrobials. J Antimicrob Chemother. 2016;71(5):1415-1425.

67. Pisano J, Pettit N, Bartlett A, Bhagat P, Han Z, Liao C. Social media as a tool for antimicrobial stewardship. Am J Infect Control. 2016;44(11):12311236.

68. Nand P, Wilson MD, Cohen SH, Brown J. Curbing antimicrobial resistance: Do physicians receive adequate education about antibiograms? J Infect. 2016;72(1):127-129.

69. Le Normand Y, Drugeon HB, Potel G, Kergueris MF, Raffi F, Milpied N, et al. Teaching individualized antibiotic dosage regimens by means of two computer-assisted learning programs. Int $\mathrm{J}$ Biomed Comput. 1994;36(1):117-119.

70. Bain DJ. Practice research. Training for general practice: clinical behaviour in trainers and trainees. Br Med J (Clin Res Ed).1984;288(6419):762-764.

71. Davey P, Garner S. Professional education on antimicrobial prescribing: a report from the Specialist Advisory Committee on Antimicrobial Resistance (SACAR) Professional Education Subgroup. J Antimicrob Chemother. 2007; 60 Suppl 1:i27-32.

72. Lodico MG, Spaulding DT, Voegtle KH. Methods in educational research: from theory to practice. John Wiley \& Sons; 2010.

73. Infectious Diseases Society of America (IDSA), Spellberg B, Blaser M, Guidos RJ, Boucher HW, Bradley JS, et al. Combating antimicrobial resistance: policy recommendations to save lives. Clin Infect Dis. 2011;52 Suppl 5:S397-428.

74. Frank JR, Snell L, Sherbino J, editors. CanMEDS 2015 Physician competency framework. Ottawa: Royal College of Physicians and Surgeons of Canada; 2015.

75. Frenk J, Chen L, Bhutta ZA, Cohen J, Crisp N, Evans T, et al. Health professionals for a new century: transforming education to strengthen health systems in an interdependent world. Lancet. 2010;376(9756):19231958. 


\section{Appendix A}

Studies with antimicrobial stewardship medical education interventions

\begin{tabular}{|c|c|c|c|c|c|c|c|}
\hline $\begin{array}{l}\text { Author, } \\
\text { year }\end{array}$ & $\begin{array}{l}\text { Article } \\
\text { type and } \\
\text { location }\end{array}$ & $\begin{array}{l}\text { Purpose of } \\
\text { intervention }\end{array}$ & Intervention design & $\begin{array}{l}\text { Target } \\
\text { learner group }\end{array}$ & $\begin{array}{l}\text { Variables } \\
\text { of interest }\end{array}$ & Results and conclusions & $\begin{array}{l}\text { Kirkpatrick } \\
\text { evaluation } \\
\text { level }^{*}\end{array}$ \\
\hline $\begin{array}{l}\text { Brennan } \\
\text { and } \\
\text { Mattock, } \\
2013\end{array}$ & $\begin{array}{l}\text { Review } \\
\text { N/A }\end{array}$ & N/A & $\begin{array}{l}\text { Intervention types include: } \\
\text { educational materials, } \\
\text { conferences and training, audit } \\
\text { and feedback, outreach visits, } \\
\text { reminders, marketing, patient- } \\
\text { mediated interventions, and } \\
\text { use of a local opinion leader. } \\
\text { Most interventions used more } \\
\text { than one strategy. }\end{array}$ & $\begin{array}{l}\text { Residents and } \\
\text { young doctors. } \\
\text { Young } \\
\text { prescribers in } \\
\text { other health } \\
\text { professions }\end{array}$ & $\begin{array}{l}\text { A variety of } \\
\text { outcome } \\
\text { measures have } \\
\text { been used, most } \\
\text { commonly rates } \\
\text { of appropri- } \\
\text { ate/inappropriate } \\
\text { prescribing }\end{array}$ & $\begin{array}{l}\text { Most interventions were } \\
\text { effective. No firm } \\
\text { conclusions can be } \\
\text { drawn about the most } \\
\text { effective type of } \\
\text { intervention, as some } \\
\text { studies found one } \\
\text { strategy effective while } \\
\text { others found the same } \\
\text { one ineffective. }\end{array}$ & $\begin{array}{l}\text { No } \\
\text { evaluation }\end{array}$ \\
\hline $\begin{array}{l}\text { Daven- } \\
\text { port et al, } \\
2005\end{array}$ & $\begin{array}{l}\text { Research } \\
\text { United } \\
\text { Kingdom }\end{array}$ & $\begin{array}{l}\text { To understand } \\
\text { outcome-based } \\
\text { education and how } \\
\text { it has been applied } \\
\text { and then been } \\
\text { implemented in } \\
\text { regards to } \\
\text { antimicrobial } \\
\text { prescribing }\end{array}$ & $\begin{array}{l}\text { A resource template for } \\
\text { teaching prudent prescribing } \\
\text { included: (i) standardized } \\
\text { vignettes covering the } 12 \\
\text { learning outcome domains; (ii) } \\
\text { a reflective patient record book, } \\
\text { including a personal antibiotic } \\
\text { formulary; (iii) discussion } \\
\text { session guidelines; (iv) } \\
\text { prescribing exercises; and (v) a } \\
\text { support resource pack. }\end{array}$ & $\begin{array}{l}\text { Medical } \\
\text { students }\end{array}$ & $\begin{array}{l}\text { Prescribing } \\
\text { patterns }\end{array}$ & $\begin{array}{l}\text { Educational approaches } \\
\text { should strive to achieve } \\
\text { predetermined outcomes } \\
\text { and the intervention } \\
\text { should be used in } \\
\text { curricula }\end{array}$ & $\begin{array}{l}\text { No } \\
\text { evaluation }\end{array}$ \\
\hline $\begin{array}{l}\text { Davey et } \\
\text { al, } 2007\end{array}$ & $\begin{array}{l}\text { Review } \\
\text { United } \\
\text { Kingdom }\end{array}$ & $\begin{array}{l}\text { To press for } \\
\text { greater coverage of } \\
\text { prudent antimi- } \\
\text { crobial use in } \\
\text { undergraduate and } \\
\text { postgraduate } \\
\text { curricula; to lead } \\
\text { in better integra- } \\
\text { tion of antimicro- } \\
\text { bial teaching in a } \\
\text { variety of settings }\end{array}$ & $\begin{array}{l}\text { Specialist Advisory Committee } \\
\text { on Antimicrobial Resistance } \\
\text { evaluating educational } \\
\text { approaches }\end{array}$ & N/A & $\begin{array}{l}\text { Attitudes and } \\
\text { belief post ASP } \\
\text { intervention } \\
\text { through ques- } \\
\text { tionnaire, number } \\
\text { of requests for } \\
\text { restricted } \\
\text { antibiotics }\end{array}$ & $\begin{array}{l}\text { Hospitals continue to use } \\
\text { different metrics in } \\
\text { surveillance but are eager } \\
\text { to collaborate. The } \\
\text { SACAR Initiative has } \\
\text { established a framework } \\
\text { for UK collaboration on } \\
\text { multi-disciplinary } \\
\text { education that will define } \\
\text { learning outcomes for all } \\
\text { health professionals. }\end{array}$ & $\begin{array}{l}\text { No } \\
\text { evaluation }\end{array}$ \\
\hline $\begin{array}{l}\text { Davey et } \\
\text { al, } 1993\end{array}$ & $\begin{array}{l}\text { Research } \\
\text { United } \\
\text { Kingdom }\end{array}$ & $\begin{array}{l}\text { To examine } \\
\text { methods of } \\
\text { determining and } \\
\text { influencing } \\
\text { antimicrobial use } \\
\text { in the UK - } \\
\text { specifically, } \\
\text { evaluating } \\
\text { undergraduate and } \\
\text { postgraduate } \\
\text { education on } \\
\text { antimicrobial } \\
\text { chemotherapy to } \\
\text { establish what info } \\
\text { is available and } \\
\text { amount and } \\
\text { content of the } \\
\text { education }\end{array}$ & $\begin{array}{l}\text { Questionnaires evaluating } \\
\text { undergraduate and postgradu- } \\
\text { ate curricula; undergraduate } \\
\text { teaching mostly lecture based, } \\
\text { postgraduate included } \\
\text { consulting specialists and using } \\
\text { material from drug infor- } \\
\text { mation centres }\end{array}$ & $\begin{array}{l}\text { Medical } \\
\text { students and } \\
\text { residents }\end{array}$ & $\begin{array}{l}\text { What are the } \\
\text { main factors that } \\
\text { influence } \\
\text { prescribing } \\
\text { behaviour }\end{array}$ & $\begin{array}{l}\text { The median amount of } \\
\text { core undergraduate } \\
\text { teaching was } 13.5 \mathrm{~h} \text { but } \\
\text { with a wide range. } \\
\text { Content was oriented } \\
\text { towards drugs rather } \\
\text { than diseases. Most } \\
\text { teaching was by formal } \\
\text { lecture as part of a core } \\
\text { programme. Postgradu- } \\
\text { ate: advice from } \\
\text { specialists and requests } \\
\text { from practitioners most } \\
\text { important determinants } \\
\text { of content. Information } \\
\text { from drug info centres } \\
\text { discussed drugs not } \\
\text { diseases. Knowledge } \\
\text { should be disseminated } \\
\text { through local networks } \\
\text { of practitioners; all } \\
\text { doctors require } \\
\text { education; need national } \\
\text { coordination of } \\
\text { information } \\
\text { dissemination }\end{array}$ & $\begin{array}{l}\text { No } \\
\text { evaluation }\end{array}$ \\
\hline
\end{tabular}




\begin{tabular}{|c|c|c|c|c|c|c|c|}
\hline $\begin{array}{l}\text { Author, } \\
\text { year }\end{array}$ & $\begin{array}{l}\text { Article } \\
\text { type and } \\
\text { location }\end{array}$ & $\begin{array}{l}\text { Purpose of } \\
\text { intervention }\end{array}$ & Intervention design & $\begin{array}{l}\text { Target } \\
\text { learner group }\end{array}$ & $\begin{array}{l}\text { Variables } \\
\text { of interest }\end{array}$ & Results and conclusions & $\begin{array}{l}\text { Kirkpatrick } \\
\text { evaluation } \\
\text { level }^{*}\end{array}$ \\
\hline $\begin{array}{l}\text { Ghafur } \\
2013\end{array}$ & $\begin{array}{l}\text { Opinion } \\
\text { India }\end{array}$ & $\begin{array}{l}\text { To reduce } \\
\text { resistance rates } \\
\text { and treat bacterial } \\
\text { infections; to } \\
\text { develop a } \\
\text { functioning policy } \\
\text { for antibiotics use } \\
\text { and infrastructure } \\
\text { for infection } \\
\text { control }\end{array}$ & $\begin{array}{l}\text { Curriculum must be revised to } \\
\text { be less didactic, focus more on } \\
\text { diseases of the tropics, rational } \\
\text { antibiotics usage, and infection } \\
\text { control. }\end{array}$ & $\begin{array}{l}\text { Medical } \\
\text { students and } \\
\text { postgraduate } \\
\text { trainees }\end{array}$ & N/A & $\begin{array}{l}\text { Incorporate more } \\
\text { infectious disease } \\
\text { training in all major } \\
\text { teaching hospitals; more } \\
\text { clinically oriented basic } \\
\text { science training }\end{array}$ & $\begin{array}{l}\text { No } \\
\text { evaluation }\end{array}$ \\
\hline $\begin{array}{l}\text { Green- } \\
\text { wood, } \\
1998\end{array}$ & $\begin{array}{l}\text { Opinion } \\
\text { United } \\
\text { Kingdom }\end{array}$ & $\begin{array}{l}\text { Antimicrobial } \\
\text { resistance is a } \\
\text { growing problem } \\
\text { that must be } \\
\text { curtailed; in order } \\
\text { for antimicrobial } \\
\text { chemotherapy to } \\
\text { have a secure } \\
\text { future, prescribers } \\
\text { must learn to use } \\
\text { these tools with } \\
\text { greater discretion }\end{array}$ & $\begin{array}{l}\text { Teaching in the UK is } \\
\text { spasmodic. Nottingham offers } \\
\text { a 2-week module on antimi- } \\
\text { crobial therapy for third year } \\
\text { students. Most schools: a few } \\
\text { lectures on principles, and } \\
\text { practical prescribing should be } \\
\text { learnt at the bedside. Postgrad- } \\
\text { uate: little is done. }\end{array}$ & $\begin{array}{l}\text { Medical } \\
\text { students and } \\
\text { residents }\end{array}$ & $\begin{array}{l}\text { Hours and types } \\
\text { of hours spent in } \\
\text { undergraduate } \\
\text { and postgraduate } \\
\text { settings }\end{array}$ & $\begin{array}{l}\text { Students are still } \\
\text { unprepared and are not } \\
\text { knowledgeable in } \\
\text { stewardship }\end{array}$ & $\begin{array}{l}\text { No } \\
\text { evaluation }\end{array}$ \\
\hline $\begin{array}{l}\text { Kerr et al, } \\
2001\end{array}$ & $\begin{array}{l}\text { Letter to } \\
\text { the editor } \\
\text { United } \\
\text { Kingdom }\end{array}$ & $\begin{array}{l}\text { To understand the } \\
\text { amount of contact } \\
\text { time allocated to } \\
\text { teaching about the } \\
\text { rational use of } \\
\text { antimicrobials at } \\
\text { UK medical } \\
\text { schools and the } \\
\text { University of St } \\
\text { Andrews }\end{array}$ & $\begin{array}{l}\text { Research study described: } \\
\text { postal survey }\end{array}$ & $\begin{array}{l}\text { Medical } \\
\text { students }\end{array}$ & $\begin{array}{l}\text { Number of } \\
\text { contact hours; } \\
\text { methods of } \\
\text { teaching }\end{array}$ & $\begin{array}{l}\text { Number of hours } \\
\text { dedicated varies greatly } \\
(0.5-22 \mathrm{~h}) \text {; difficult to } \\
\text { quantify exposure during } \\
\text { teaching of other topics } \\
\text { and in clinical setting; } \\
\text { main methods of } \\
\text { teaching was generally } \\
\text { lectures, but also } \\
\text { supplemented with } \\
\text { tutorials and learning } \\
\text { exercises, as well as self- } \\
\text { directed learning }\end{array}$ & $\begin{array}{l}\text { No } \\
\text { evaluation }\end{array}$ \\
\hline $\begin{array}{l}\text { Le } \\
\text { Normand } \\
\text { et al, } 1994\end{array}$ & $\begin{array}{l}\text { Research } \\
\text { France }\end{array}$ & $\begin{array}{l}\text { To develop a } \\
\text { program to help } \\
\text { teach the basic } \\
\text { principles of } \\
\text { antibiotic } \\
\text { monitoring for } \\
\text { time-dependent } \\
\text { and concentration- } \\
\text { dependent } \\
\text { bactericidal } \\
\text { molecules }\end{array}$ & $\begin{array}{l}\text { Multidisciplinary tutorial } \\
\text { programs. Students given } \\
\text { clinical case information, and } \\
\text { plan treatment. System } \\
\text { evaluates students' choice and } \\
\text { provides commentary to } \\
\text { evaluate the efficacy of } \\
\text { treatment }\end{array}$ & Does not state & Not stated & $\begin{array}{l}\text { Programs are compli- } \\
\text { mentary to conventional } \\
\text { teaching }\end{array}$ & $\begin{array}{l}\text { No } \\
\text { evaluation }\end{array}$ \\
\hline $\begin{array}{l}\text { Lee et al, } \\
2013\end{array}$ & $\begin{array}{l}\text { Review } \\
\text { N/A }\end{array}$ & $\begin{array}{l}\text { To summarize and } \\
\text { discuss various } \\
\text { strategies to } \\
\text { minimize } \\
\text { antibiotic } \\
\text { resistance }\end{array}$ & N/A & $\begin{array}{l}\text { Medical } \\
\text { students post- } \\
\text { graduate } \\
\text { trainees, staff }\end{array}$ & $\begin{array}{l}\text { Courses in } \\
\text { numbers and } \\
\text { days, number of } \\
\text { inappropriate } \\
\text { prescriptions, } \\
\text { number of } \\
\text { duplicative gram- } \\
\text { negative coverage } \\
\text { with iv fluoro- } \\
\text { quinolones, } \\
\text { duration of } \\
\text { inappropriate use }\end{array}$ & $\begin{array}{l}\text { Decreasing resistance } \\
\text { requires involvement of } \\
\text { students, staff, and the } \\
\text { public. While much } \\
\text { education has been } \\
\text { targeted at staff and } \\
\text { some at children, } \\
\text { undergraduate training } \\
\text { courses would be } \\
\text { successful if the students } \\
\text { are imparted with } \\
\text { adequate knowledge, and } \\
\text { trained in developing the } \\
\text { right attitude and } \\
\text { behavior. All health } \\
\text { professions require } \\
\text { teaching }\end{array}$ & $\begin{array}{l}\text { No } \\
\text { evaluation }\end{array}$ \\
\hline
\end{tabular}


Silverberg et al. Antimicrobial stewardship training in medical education

\begin{tabular}{|c|c|c|c|c|c|c|c|}
\hline $\begin{array}{l}\text { Author, } \\
\text { year }\end{array}$ & $\begin{array}{l}\text { Article } \\
\text { type and } \\
\text { location }\end{array}$ & $\begin{array}{l}\text { Purpose of } \\
\text { intervention }\end{array}$ & Intervention design & $\begin{array}{l}\text { Target } \\
\text { learner group }\end{array}$ & $\begin{array}{l}\text { Variables } \\
\text { of interest }\end{array}$ & Results and conclusions & $\begin{array}{l}\text { Kirkpatrick } \\
\text { evaluation } \\
\text { level* }\end{array}$ \\
\hline $\begin{array}{l}\text { Lee et al, } \\
2015\end{array}$ & $\begin{array}{l}\text { Review } \\
\text { N/A }\end{array}$ & $\begin{array}{l}\text { To investigate } \\
\text { recent studies on } \\
\text { the effect of } \\
\text { interventions for } \\
\text { promoting prudent } \\
\text { antibiotics } \\
\text { prescribing, }\end{array}$ & N/A & $\begin{array}{l}\text { Medical } \\
\text { students and } \\
\text { staff }\end{array}$ & $\begin{array}{l}\text { Usage of } \\
\text { diagnostic tests, } \\
\text { choice of } \\
\text { antibiotics, } \\
\text { clinical outcomes } \\
\text { (length of } \\
\text { antibiotic } \\
\text { treatment, length } \\
\text { of stay, mortality) }\end{array}$ & $\begin{array}{l}\text { There is no randomized } \\
\text { control trial study } \\
\text { assessing the effective- } \\
\text { ness of educational } \\
\text { programs for medical } \\
\text { students. There is no } \\
\text { study measuring the } \\
\text { effectiveness of an } \\
\text { educational program on } \\
\text { prudent antibiotic } \\
\text { prescribing for medical } \\
\text { students }\end{array}$ & $\begin{array}{l}\text { No } \\
\text { evaluation }\end{array}$ \\
\hline $\begin{array}{l}\text { Luther et } \\
\text { al, } 2013\end{array}$ & $\begin{array}{l}\text { Letter to } \\
\text { the editor } \\
\text { United } \\
\text { States }\end{array}$ & $\begin{array}{l}\text { To increase } \\
\text { appropriate } \\
\text { antibiotic use }\end{array}$ & $\begin{array}{l}\text { Antimicrobial stewardship } \\
\text { pilot curriculum: didactic } \\
\text { presentations and exam } \\
\text { questions in USMLE format; } \\
\text { clinical years have small-group } \\
\text { activities }\end{array}$ & $\begin{array}{l}\text { Medical } \\
\text { students }\end{array}$ & N/A & N/A & $\begin{array}{l}\text { No } \\
\text { evaluation }\end{array}$ \\
\hline $\begin{array}{l}\text { McNulty, } \\
\text { Cookson } \\
\text { and } \\
\text { Lewis, } \\
2012\end{array}$ & $\begin{array}{l}\text { Program } \\
\text { descrip- } \\
\text { tion } \\
\text { United } \\
\text { Kingdom }\end{array}$ & $\begin{array}{l}\text { Examines what is } \\
\text { currently being } \\
\text { done in terms of } \\
\text { antimicrobial } \\
\text { stewardship in the } \\
\text { UK / in Europe }\end{array}$ & $\begin{array}{l}\text { Inclusion of hygiene and } \\
\text { aseptic practice in the induc- } \\
\text { tion for the foundation years; } \\
\text { infection control procedures } \\
\text { are key competencies in second } \\
\text { year; inclusion of infection } \\
\text { control in appraisal for } \\
\text { foundation year and specialist } \\
\text { registrar trainees; infection } \\
\text { control elements within the } \\
\text { exams of Royal Colleges }\end{array}$ & $\begin{array}{l}\text { Undergradu- } \\
\text { ate, post- } \\
\text { graduate, } \\
\text { public, staff }\end{array}$ & N/A & $\begin{array}{l}\text { The CMO is at the point } \\
\text { where they are asking if } \\
\text { it is indeed being taught / } \\
\text { included at an undergrad } \\
\text { and postgrad level }\end{array}$ & $\begin{array}{l}\text { No } \\
\text { evaluation }\end{array}$ \\
\hline $\begin{array}{l}\text { Philp, } \\
\text { Wilford } \\
\text { and Low, } \\
1986\end{array}$ & $\begin{array}{l}\text { Research } \\
\text { United } \\
\text { Kingdom }\end{array}$ & $\begin{array}{l}\text { To better define } \\
\text { the scope of the } \\
\text { failure for } \\
\text { residents to } \\
\text { prescribe rationally } \\
\text { despite their } \\
\text { lecture-based } \\
\text { training }\end{array}$ & $\begin{array}{l}\text { Research pharmacist examined } \\
\text { ward prescription sheets and } \\
\text { questioned residents about } \\
\text { antimicrobial orders compared } \\
\text { to labs if labs ordered }\end{array}$ & Residents & $\begin{array}{l}\text { Number of } \\
\text { antimicrobial } \\
\text { prescriptions } \\
\text { written; before or } \\
\text { after labs; rational } \\
\text { and appropriate } \\
\text { prescription of } \\
\text { antibiotics }\end{array}$ & $\begin{array}{l}\text { Residents prescribed } \\
\text { rationally when they had } \\
\text { seen the labs but } \\
\text { prescribed inappropri- } \\
\text { ately if they did so before } \\
\text { labs came back. } \\
\text { Residents do not follow } \\
\text { the methodology they } \\
\text { were taught in class }\end{array}$ & $\begin{array}{l}\text { No } \\
\text { evaluation }\end{array}$ \\
\hline $\begin{array}{l}\text { Pulcini } \\
\text { and } \\
\text { Gyssens, } \\
2013\end{array}$ & $\begin{array}{l}\text { Review } \\
\text { N/A }\end{array}$ & $\begin{array}{l}\text { To educate } \\
\text { medical students } \\
\text { on principles of } \\
\text { microbiology, } \\
\text { infectious diseases } \\
\text { and clinical } \\
\text { pharmacology, and } \\
\text { on prudent } \\
\text { prescribing of } \\
\text { antibiotics }\end{array}$ & N/A & $\begin{array}{l}\text { Medical } \\
\text { students, } \\
\text { children, } \\
\text { junior doctors, } \\
\text { staff }\end{array}$ & $\begin{array}{l}\text { When should } \\
\text { antimicrobial } \\
\text { stewardship } \\
\text { education start; } \\
\text { who should } \\
\text { educate; how } \\
\text { should they be } \\
\text { educated }\end{array}$ & $\begin{array}{l}\text { Education should exist in } \\
\text { medical school starting } \\
\text { in year } 3 \text { of a } 4 \text { year } \\
\text { program, not just in } \\
\text { post-graduate setting }\end{array}$ & $\begin{array}{l}\text { No } \\
\text { evaluation }\end{array}$ \\
\hline $\begin{array}{l}\text { Pulcini et } \\
\text { al, } 2015\end{array}$ & $\begin{array}{l}\text { Research } \\
\text { Europe }\end{array}$ & $\begin{array}{l}\text { To educate } \\
\text { European medical } \\
\text { students; to } \\
\text { determine } \\
\text { antibiotic } \\
\text { education in } \\
\text { medical curricula }\end{array}$ & $\begin{array}{l}\text { Questionnaire and interviews } \\
\text { with lecturers to evaluate } \\
\text { medical school curricula }\end{array}$ & $\begin{array}{l}\text { Medical } \\
\text { Students }\end{array}$ & $\begin{array}{l}\text { Teaching } \\
\text { principles for } \\
\text { prudent antibiotic } \\
\text { use in undergrad- } \\
\text { uate curriculum; } \\
\text { Association } \\
\text { among curricu- } \\
\text { lum, antibiotic use } \\
\text { and/or rates of } \\
\text { bacterial re- } \\
\text { sistance at the } \\
\text { country level }\end{array}$ & $\begin{array}{l}\text { Prudent antibiotic use } \\
\text { principles were taught in } \\
\text { all but one school, but } \\
\text { only } 4 / 13 \text { countries had a } \\
\text { national programme. } \\
\text { Interactive teaching } \\
\text { formats were used less } \\
\text { frequently than passive } \\
\text { formats: clinical case } \\
\text { discussions, active } \\
\text { learning assignments, } \\
\text { web-based server } \\
\text { software learning } \\
\text { platform, E-learning, }\end{array}$ & $\begin{array}{l}\text { No } \\
\text { evaluation }\end{array}$ \\
\hline
\end{tabular}




\begin{tabular}{|c|c|c|c|c|c|c|c|}
\hline $\begin{array}{l}\text { Author, } \\
\text { year }\end{array}$ & $\begin{array}{l}\text { Article } \\
\text { type and } \\
\text { location }\end{array}$ & $\begin{array}{l}\text { Purpose of } \\
\text { intervention }\end{array}$ & Intervention design & $\begin{array}{l}\text { Target } \\
\text { learner group }\end{array}$ & $\begin{array}{l}\text { Variables } \\
\text { of interest }\end{array}$ & Results and conclusions & $\begin{array}{l}\text { Kirkpatrick } \\
\text { evaluation } \\
\text { level }^{*}\end{array}$ \\
\hline
\end{tabular}

role-play were used

variably; lectures were

used in all cases.

Opportunities for

implementation in

curricula were variable.

There was no significant

association between the

level of teaching of

prudent antibiotic use

and either prevalence of

bacterial resistance,

outpatient antibiotic use

and total antibiotic use.

Lack of time one of the

main constraints

preventing it from being

included more heavily in

curricula. There is wide

variation even amongst

students within the same

country in terms of

exposure to antibiotic

prescribing principles.

\begin{tabular}{|c|c|c|c|c|c|c|c|}
\hline $\begin{array}{l}\text { Shankar } \\
\text { et al } 2011\end{array}$ & $\begin{array}{l}\text { Program } \\
\text { descrip- } \\
\text { tion } \\
\text { Nepal }\end{array}$ & $\begin{array}{l}\text { To improve } \\
\text { teaching of } \\
\text { antibiotics to } \\
\text { medical students }\end{array}$ & $\begin{array}{l}\text { Problem-based learning used } \\
\text { to teach pharmacology with } 10 \\
\text { developed subject areas that } \\
\text { students should learn in } \\
\text { pharmacology }\end{array}$ & $\begin{array}{l}\text { Medical } \\
\text { students }\end{array}$ & N/A & $\begin{array}{l}\text { Rational use of antibiot- } \\
\text { ics has been embedded } \\
\text { throughout a small } \\
\text { group module. The } \\
\text { module with modifica- } \\
\text { tions can be considered } \\
\text { for inclusion in other } \\
\text { medical schools }\end{array}$ & $\begin{array}{l}\text { No } \\
\text { evaluation }\end{array}$ \\
\hline
\end{tabular}

\begin{tabular}{|c|c|c|c|c|c|c|c|}
\hline $\begin{array}{l}\text { Wright } \\
\text { and Jain, } \\
2004\end{array}$ & $\begin{array}{l}\text { Opinion } \\
\text { United } \\
\text { Kingdom }\end{array}$ & $\begin{array}{l}\text { To review } \\
\text { undergraduate } \\
\text { medical education } \\
\text { on AMR }\end{array}$ & $\begin{array}{l}\text { Survey on knowledge of } \\
\text { antibiotics and resistance were } \\
\text { given to final year medical } \\
\text { students before additional } \\
\text { teaching. Spread teaching by } \\
\text { medical microbiologists } \\
\text { (tutorials) }\end{array}$ & $\begin{array}{l}\text { Medical } \\
\text { Students }\end{array}$ & $\begin{array}{l}\text { Knowledge of } \\
\text { antibiotics and of } \\
\text { resistant organ- } \\
\text { isms; no analysis } \\
\text { given on } \\
\text { interventions }\end{array}$ & $\begin{array}{l}\text { Students do not always } \\
\text { know the brand names of } \\
\text { generic drugs; students } \\
\text { had a good understand- } \\
\text { ing of resistant organ- } \\
\text { isms but overestimated } \\
\text { antibiotics prescription } \\
\text { rates in hospital. No } \\
\text { analysis given on } \\
\text { intervention }\end{array}$ & $\begin{array}{l}\text { Level } 2 \text { of } \\
\text { medical } \\
\text { students, } \\
\text { but no } \\
\text { evaluation } \\
\text { of the } \\
\text { additional } \\
\text { teaching }\end{array}$ \\
\hline
\end{tabular}

\begin{tabular}{|c|c|c|c|c|c|c|c|}
\hline $\begin{array}{l}\text { Bannan et } \\
\text { al, } 2009\end{array}$ & $\begin{array}{l}\text { Research } \\
\text { Australia }\end{array}$ & $\begin{array}{l}\text { To elicit attitudes } \\
\text { of the ASP's aims, } \\
\text { utility, educational } \\
\text { value, effect on } \\
\text { patient care and } \\
\text { ease of use }\end{array}$ & $\begin{array}{l}\text { Self-administered question- } \\
\text { naire, ASP program required } \\
\text { receiving ID approval of } \\
\text { restricted antibiotics, attitudi- } \\
\text { nal and belief questions } \\
\text { measured. }\end{array}$ & $\begin{array}{l}\text { Interns, RMO } \\
\text { and staff }\end{array}$ & $\begin{array}{l}\text { Knowledge, } \\
\text { attitudes and } \\
\text { beliefs on the } \\
\text { system; use of the } \\
\text { system }\end{array}$ & $\begin{array}{l}98 \% \text { of staff found ASP } \\
\text { reasonable. Most } \\
\text { believed it made teams } \\
\text { think carefully about } \\
\text { antibiotic choice. It was } \\
\text { time-consuming and } \\
\text { detracted from clinical } \\
\text { duties. Intervention was } \\
\text { believed by most to } \\
\text { improve patient } \\
\text { outcomes. }\end{array}$ & Level 1 \\
\hline
\end{tabular}

\begin{tabular}{|c|c|c|c|c|c|c|c|}
\hline $\begin{array}{l}\text { Beylefeld } \\
\text { and Struw } \\
\text { ig, } 2007\end{array}$ & $\begin{array}{l}\text { Research } \\
\text { South } \\
\text { Africa }\end{array}$ & $\begin{array}{l}\text { To improve } \\
\text { medical microbi- } \\
\text { ology teaching and } \\
\text { students enthusi- } \\
\text { asm for it }\end{array}$ & Quiz-type board game & $\begin{array}{l}\text { Medical } \\
\text { students }\end{array}$ & $\begin{array}{l}\text { Two question- } \\
\text { naire surveys, a } \\
\text { focus group } \\
\text { interview, direct } \\
\text { observation and } \\
\text { the nominal } \\
\text { group technique }\end{array}$ & $\begin{array}{l}\text { Game format effective in } \\
\text { improving student } \\
\text { engagement }\end{array}$ & Level 1 \\
\hline
\end{tabular}


Silverberg et al. Antimicrobial stewardship training in medical education

\begin{tabular}{|c|c|c|c|c|c|c|c|}
\hline $\begin{array}{l}\text { Author, } \\
\text { year }\end{array}$ & $\begin{array}{l}\text { Article } \\
\text { type and } \\
\text { location }\end{array}$ & $\begin{array}{l}\text { Purpose of } \\
\text { intervention }\end{array}$ & Intervention design & $\begin{array}{l}\text { Target } \\
\text { learner group }\end{array}$ & $\begin{array}{l}\text { Variables } \\
\text { of interest }\end{array}$ & Results and conclusions & $\begin{array}{l}\text { Kirkpatrick } \\
\text { evaluation } \\
\text { level }^{*}\end{array}$ \\
\hline $\begin{array}{l}\text { Cheun- } \\
\text { chom et } \\
\text { al, } 2016\end{array}$ & $\begin{array}{l}\text { Research } \\
\text { Thailand }\end{array}$ & $\begin{array}{l}\text { To identify } \\
\text { knowledge, } \\
\text { perception \& } \\
\text { attitudes concern- } \\
\text { ing antimicrobial } \\
\text { resistance \& } \\
\text { infection control } \\
\text { among final year } \\
\text { medical students }\end{array}$ & $\begin{array}{l}\text { Questionnaire-based study } \\
\text { among final year Thai medical } \\
\text { students }\end{array}$ & $\begin{array}{l}\text { Final year } \\
\text { undergraduate } \\
\text { medical } \\
\text { students }\end{array}$ & $\begin{array}{l}\text { Survey assessed } \\
\text { student's } \\
\text { perception and } \\
\text { attitudes towards } \\
\text { AMR, and } \\
\text { knowledge of } \\
\text { AMR/ infection } \\
\text { control. Further } \\
\text { educational } \\
\text { activities and } \\
\text { hospital structure } \\
\text { were examined }\end{array}$ & $\begin{array}{l}\text { Student's knowledge } \\
\text { concerning AMR, } \\
\text { appropriate usage and } \\
\text { infection control was } \\
\text { limited. Only half of } \\
\text { students recognized the } \\
\text { existence of an AMS } \\
\text { program or infection } \\
\text { control unit in their } \\
\text { hospitals, highlighting } \\
\text { poor access and gaps in } \\
\text { current medical } \\
\text { education at these } \\
\text { institutions }\end{array}$ & Level 1 \\
\hline $\begin{array}{l}\text { Gharbi et } \\
\text { al. } 2016\end{array}$ & $\begin{array}{l}\text { Research } \\
\text { United } \\
\text { Kingdom }\end{array}$ & $\begin{array}{l}\text { To identify junior } \\
\text { doctor's } \\
\text { knowledge, } \\
\text { attitude, behav- } \\
\text { iours concerning } \\
\text { antimicrobial } \\
\text { prescription so as } \\
\text { to identify key } \\
\text { areas to address } \\
\text { future educational } \\
\text { programs }\end{array}$ & $\begin{array}{l}\text { Cross-sectional survey } \\
\text { investigating junior doctor's } \\
\text { antimicrobial prescribing } \\
\text { practices \& educational needs }\end{array}$ & $\begin{array}{l}140 \text { Junior } \\
\text { doctors, form } \\
5 \text { London } \\
\text { hospitals }\end{array}$ & $\begin{array}{l}\text { Survey assessed } \\
\text { prescribing } \\
\text { behaviour of } \\
\text { junior doctors, } \\
\text { prescribing } \\
\text { education \& } \\
\text { support in the } \\
\text { hospital through a } \\
\text { needs- based } \\
\text { assessment. } \\
\text { Multiple logistic } \\
\text { regression } \\
\text { examined factors } \\
\text { associated with } \\
\text { confidence } \\
\text { prescribing Abx } \\
\text { as a junior doctor }\end{array}$ & $\begin{array}{l}\text { A significant proportion } \\
\text { of junior doctors } \\
\text { reported prescribing of } \\
\text { antimicrobials in the } \\
\text { context of low self- } \\
\text { perceived confidence and } \\
\text { knowledge and had } \\
\text { difficulty in accessing } \\
\text { aid. } 5 \text { specific areas } \\
\text { needed to bolster junior } \\
\text { doctors practicing in } \\
\text { secondary care. Specific } \\
\text { areas of educational need } \\
\text { included: principles of } \\
\text { antimicrobial prescrib- } \\
\text { ing, diagnosis of } \\
\text { infections, clinical review } \\
\text { of patients c infections, } \\
\text { prescribing in context of } \\
\text { AMR \& laboratory } \\
\text { testing/ test results }\end{array}$ & Level 1 \\
\hline $\begin{array}{l}\text { Haque et } \\
\text { al. } 2016\end{array}$ & $\begin{array}{l}\text { Research } \\
\text { University } \\
\text { of Sultan } \\
\text { Zainal } \\
\text { Abidin, } \\
\text { Malaysia }\end{array}$ & $\begin{array}{l}\text { Assess medical } \\
\text { students' } \\
\text { knowledge } \\
\text { regarding } \\
\text { antimicrobial } \\
\text { resistance and } \\
\text { prescribing and to } \\
\text { identify any gaps } \\
\text { in education }\end{array}$ & $\begin{array}{l}\text { Cross-sectional, questionnaire- } \\
\text { based survey }\end{array}$ & $\begin{array}{l}\text { Medical } \\
\text { Students (year } \\
3,4 \& 5 \text { ) }\end{array}$ & $\begin{array}{l}\text { Questionnaire } \\
\text { consisted of } 21 \\
\text { questions to } \\
\text { assess: confidence } \\
\text { in prescription, } \\
\text { AMR knowledge, } \\
\text { amount of } \\
\text { training in } \\
\text { undergrad studies } \\
\text { and self-reported } \\
\text { antibiotics usage }\end{array}$ & $\begin{array}{l}\text { There is an educational } \\
\text { gap between theoretical } \\
\text { input and clinical } \\
\text { practice in terms of AMR } \\
\text { and antibiotics prescrip- } \\
\text { tion. The majority of } \\
\text { students ( } 88 \% \text { ) stated } \\
\text { desiring more training in } \\
\text { their current curriculum } \\
\text { concerning antibiotic } \\
\text { selection and theory. }\end{array}$ & Level 1 \\
\hline $\begin{array}{l}\text { Hoque, } \\
\text { Mostafa, } \\
\text { Haque et } \\
\text { al. } 2016\end{array}$ & $\begin{array}{l}\text { Research } \\
\text { Chitta- } \\
\text { gong, } \\
\text { Bangla- } \\
\text { desh }\end{array}$ & $\begin{array}{l}\text { To gain insight of } \\
\text { medical students } \\
\text { concerning } \\
\text { antimicrobial } \\
\text { prescribing and } \\
\text { resistance, } \\
\text { assessing readiness } \\
\text { from education at } \\
\text { private school in } \\
\text { Bangladesh }\end{array}$ & $\begin{array}{l}\text { Cross sectional, randomized, } \\
\text { questionnaire based study }\end{array}$ & $\begin{array}{l}\text { Medical } \\
\text { students (years } \\
3,4 \& 5 \\
\text { (clinical year } \\
\text { in Bangladesh) }\end{array}$ & $\begin{array}{l}\text { Survey assessed } \\
\text { student's } \\
\text { confidence in } \\
\text { AMR \& prescrip- } \\
\text { tion practices, } \\
\text { knowledge, } \\
\text { amount of } \\
\text { training received } \\
\text { in curricula and } \\
\text { self-reported } \\
\text { practices of } \\
\text { antimicrobial } \\
\text { usage }\end{array}$ & $\begin{array}{l}\text { Students had a lack of } \\
\text { confidence in the context } \\
\text { of AMR/prescription } \\
\text { practices due to a } \\
\text { knowledge gap in the } \\
\text { proper selection of } \\
\text { antimicrobials. }\end{array}$ & Level 1 \\
\hline
\end{tabular}




\begin{tabular}{|c|c|c|c|c|c|c|c|}
\hline $\begin{array}{l}\text { Author, } \\
\text { year }\end{array}$ & $\begin{array}{l}\text { Article } \\
\text { type and } \\
\text { location }\end{array}$ & $\begin{array}{l}\text { Purpose of } \\
\text { intervention }\end{array}$ & Intervention design & $\begin{array}{l}\text { Target } \\
\text { learner group }\end{array}$ & $\begin{array}{l}\text { Variables } \\
\text { of interest }\end{array}$ & Results and conclusions & $\begin{array}{l}\text { Kirkpatrick } \\
\text { evaluation } \\
\text { level }\end{array}$ \\
\hline $\begin{array}{l}\text { Minen et } \\
\text { al, } 2010\end{array}$ & $\begin{array}{l}\text { Research } \\
\text { United } \\
\text { States }\end{array}$ & $\begin{array}{l}\text { To understand } \\
\text { medical students } \\
\text { perceptions of } \\
\text { their medical } \\
\text { education; to } \\
\text { identify gaps in } \\
\text { medical education }\end{array}$ & $\begin{array}{l}\text { Online survey on perceptions } \\
\text { and attitudes of their training } \\
\text { in antibiotics. Curriculum had } \\
\text { pharmacology and an infec- } \\
\text { tious disease courses that } \\
\text { included antimicrobial } \\
\text { treatment selection }\end{array}$ & $\begin{array}{l}\text { Medical } \\
\text { students }\end{array}$ & $\begin{array}{l}\text { Student opinions } \\
\text { and preferences } \\
\text { on importance of } \\
\text { antibiotics and } \\
\text { resistance, } \\
\text { feedback and } \\
\text { teaching; where } \\
\text { students access } \\
\text { knowledge; basic } \\
\text { knowledge of } \\
\text { organisms and } \\
\text { resistance }\end{array}$ & $\begin{array}{l}\text { Student recognition of } \\
\text { importance of topic and } \\
\text { want more instruction. } \\
\text { Medical school curricula } \\
\text { should be expanded to } \\
\text { provide additional } \\
\text { training timed with their } \\
\text { clinical rotations. } \\
\text { Students have no clear } \\
\text { preference for digital } \\
\text { reference use for self- } \\
\text { directed continuing } \\
\text { education. }\end{array}$ & Level 1 \\
\hline $\begin{array}{l}\text { Nifakos, } \\
\text { Tomson } \\
\text { and Zary, } \\
2014\end{array}$ & $\begin{array}{l}\text { Research } \\
\text { Sweden }\end{array}$ & $\begin{array}{l}\text { To investigate } \\
\text { educational } \\
\text { approaches using } \\
\text { the real physical } \\
\text { context to enrich } \\
\text { the educational on } \\
\text { antibiotics } \\
\text { prescribing }\end{array}$ & $\begin{array}{l}\text { Augmented reality using a drug } \\
\text { box }\end{array}$ & Residents & $\begin{array}{l}\text { Design-Based } \\
\text { Research } \\
\text { Methodology: } \\
\text { problem analysis, } \\
\text { investigation of } \\
\text { information that } \\
\text { should be } \\
\text { visualized for the } \\
\text { training session, } \\
\text { and finally the } \\
\text { involvement of } \\
\text { the end users the } \\
\text { development and } \\
\text { evaluation } \\
\text { processes of the } \\
\text { prototype. }\end{array}$ & $\begin{array}{l}\text { Must further examine } \\
\text { how augmented reality } \\
\text { could contribute to the } \\
\text { improvement of } \\
\text { competencies among } \\
\text { healthcare professionals } \\
\text { and decrease of antibiot- } \\
\text { ics resistance. The } \\
\text { prototype needs further } \\
\text { development; it had a } \\
\text { high level of acceptance } \\
\text { amongst students }\end{array}$ & Level 1 \\
\hline $\begin{array}{l}\text { Priyash- } \\
\text { eelta et al. } \\
2016\end{array}$ & $\begin{array}{l}\text { Research, } \\
\text { letter to } \\
\text { the editor } \\
\text { United } \\
\text { States }\end{array}$ & $\begin{array}{l}\text { Evaluate medical } \\
\text { trainees' } \\
\text { knowledge \& } \\
\text { education } \\
\text { regarding } \\
\text { antibiograms }\end{array}$ & 20-item survey & $\begin{array}{l}\text { Postgraduate } \\
\text { medical } \\
\text { students } \\
\text { (residents \& } \\
\text { interns) }\end{array}$ & $\begin{array}{l}\text { Survey assessed } \\
\text { resident/ intern's } \\
\text { education } \\
\text { surrounding } \\
\text { antibiograms: } \\
\text { comprised of } \\
\text { knowledge- based } \\
\text { questions } \\
\text { (including } \\
\text { antibiograms/ } \\
\text { breaking point) \& } \\
\text { sources of } \\
\text { education related } \\
\text { to antibiograms }\end{array}$ & $\begin{array}{l}\text { Study found that medical } \\
\text { trainees receive limited } \\
\text { education surrounding } \\
\text { AMR/AM prescription - } \\
\text { specifically, this study } \\
\text { highlights that educa- } \\
\text { tion- surrounding } \\
\text { antibiograms is deficient } \\
\text { \& requires further } \\
\text { coverage in curricula. } \\
\text { Almost all resi- } \\
\text { dents/interns were } \\
\text { familiar with the } \\
\text { definition of an antibio- } \\
\text { gram, but only } 62.2 \% \\
\text { correctly identified the } \\
\text { definition of a 'break- } \\
\text { point,' and } 77.9 \% \text { knew } \\
\text { how to obtain their } \\
\text { institution's antibiogram. }\end{array}$ & Level 1 \\
\hline $\begin{array}{l}\text { Marwick } \\
\text { and } \\
\text { Nathwani } \\
, 2007\end{array}$ & $\begin{array}{l}\text { Letter to } \\
\text { the editor } \\
\text { United } \\
\text { Kingdom }\end{array}$ & $\begin{array}{l}\text { To improve } \\
\text { appropriate } \\
\text { antibiotic } \\
\text { prescription }\end{array}$ & $\begin{array}{l}\text { Promotion of local good } \\
\text { practice guidelines, audits of } \\
\text { knowledge and behaviour. An } \\
\text { outcome based web-based } \\
\text { program for teaching and } \\
\text { reflecting on learning of } \\
\text { antibiotics prescribing }\end{array}$ & $\begin{array}{l}\text { Medical } \\
\text { students }\end{array}$ & $\begin{array}{l}\text { Student and staff } \\
\text { feedback; student } \\
\text { knowledge } \\
\text { evaluated through } \\
\text { exams }\end{array}$ & $\begin{array}{l}\text { More clinically focused } \\
\text { teaching through such } \\
\text { web-based approaches } \\
\text { can effectively improve } \\
\text { students knowledge }\end{array}$ & $\begin{array}{l}\text { Levels } 1 \\
\text { and Level } 2\end{array}$ \\
\hline $\begin{array}{l}\text { Valente et } \\
\text { al, } 2009\end{array}$ & $\begin{array}{l}\text { Research } \\
\text { Brazil }\end{array}$ & $\begin{array}{l}\text { To integrate basic } \\
\text { Bacteriology with } \\
\text { mechanisms of } \\
\text { action of antimi- } \\
\text { crobial agents }\end{array}$ & $\begin{array}{l}\text { Board game to teach students } \\
\text { about antibiotics and resistance }\end{array}$ & $\begin{array}{l}\text { Medical } \\
\text { students and } \\
\text { pharmacy } \\
\text { students } \\
\text { (undergradu- } \\
\text { ate) }\end{array}$ & $\begin{array}{l}\text { Knowledge pre- } \\
\text { and post- } \\
\text { intervention; } \\
\text { survey on whether } \\
\text { students liked the } \\
\text { game, and } \\
\text { whether they }\end{array}$ & $\begin{array}{l}\text { There was an increase in } \\
\text { the number of right } \\
\text { answers and a decrease } \\
\text { in the number of } \\
\text { unknown answers. There } \\
\text { were no significant } \\
\text { differences between the }\end{array}$ & $\begin{array}{l}\text { Level } 1 \text { and } \\
2\end{array}$ \\
\hline
\end{tabular}


Silverberg et al. Antimicrobial stewardship training in medical education

\begin{tabular}{|c|c|c|c|c|c|c|c|}
\hline $\begin{array}{l}\text { Author, } \\
\text { year }\end{array}$ & $\begin{array}{l}\text { Article } \\
\text { type and } \\
\text { location }\end{array}$ & $\begin{array}{l}\text { Purpose of } \\
\text { intervention }\end{array}$ & Intervention design & $\begin{array}{l}\text { Target } \\
\text { learner group }\end{array}$ & $\begin{array}{l}\text { Variables } \\
\text { of interest }\end{array}$ & Results and conclusions & $\begin{array}{l}\text { Kirkpatrick } \\
\text { evaluation } \\
\text { level }^{*}\end{array}$ \\
\hline & & & & & $\begin{array}{l}\text { found it an } \\
\text { effective learning } \\
\text { tool, etc. }\end{array}$ & courses. & \\
\hline $\begin{array}{l}\text { Welch et } \\
\text { al, } 2000\end{array}$ & $\begin{array}{l}\text { Research } \\
\text { United } \\
\text { Kingdom }\end{array}$ & $\begin{array}{l}\text { To promote } \\
\text { rational antibiotic } \\
\text { and analgesic } \\
\text { prescribing for } \\
\text { non-inpatients } \\
\text { attending an } \\
\text { emergency } \\
\text { department }\end{array}$ & $\begin{array}{l}\text { Survey, intervention (prescrip- } \\
\text { tion pad including a summary } \\
\text { of clinical condition) reviewed } \\
\text { by panel of experts and rated } \\
\text { for appropriateness, followed } \\
\text { by educational period, which } \\
\text { included lectures, discussion } \\
\text { groups, and guideline promo- } \\
\text { tion. Survey and review were } \\
\text { repeated }\end{array}$ & $\begin{array}{l}\text { Junior medical } \\
\text { officers }\end{array}$ & $\begin{array}{l}\text { 'Non-inpatient' } \\
\text { prescriptions were } \\
\text { collected before } \\
\text { education and } \\
\text { afterwards. }\end{array}$ & $\begin{array}{l}\text { Not statistically } \\
\text { significant improvement } \\
\text { in antibiotic prescribing } \\
\text { trends; use of guidelines } \\
\text { did markedly increase. A } \\
\text { method has been } \\
\text { developed to educate } \\
\text { JMOs on therapeutics in } \\
\text { the ED that led to a trend } \\
\text { in improvement in } \\
\text { prescribing of antibiotics } \\
\text { but little change in } \\
\text { analgesic prescribing. } \\
\text { The program was very } \\
\text { well accepted by the } \\
\text { JMOs }\end{array}$ & $\begin{array}{l}\text { Levels } 1 \\
\text { and } 3\end{array}$ \\
\hline $\begin{array}{l}\text { Temte et } \\
\text { al, } 1999\end{array}$ & $\begin{array}{l}\text { Research } \\
\text { United } \\
\text { States }\end{array}$ & $\begin{array}{l}\text { To improve viral } \\
\text { surveillance and } \\
\text { improve family } \\
\text { medicine residents } \\
\text { prescribing of } \\
\text { antibiotics }\end{array}$ & $\begin{array}{l}\text { Viral surveillance program as } \\
\text { well as detailed educational } \\
\text { seminar on respiratory viruses. } \\
\text { Chart review to evaluate } \\
\text { antibiotics prescription rates } \\
\text { and upper respiratory } \\
\text { infections }\end{array}$ & Residents & $\begin{array}{l}\text { Familiarity with } \\
\text { system and } \\
\text { evaluation of } \\
\text { training in terms } \\
\text { of knowledge } \\
\text { provided and its } \\
\text { usefulness; rates } \\
\text { of antibiotic } \\
\text { prescribing in } \\
\text { senior residents }\end{array}$ & $\begin{array}{l}\text { By PGY-3 year, } 79 \% \text { felt } \\
\text { their education and } \\
\text { training had provided } \\
\text { adequate knowledge. } \\
\text { Most knew about the } \\
\text { surveillance program but } \\
\text { only } 42 \% \text { pay attention } \\
\text { to surveillance reports. } \\
86 \% \text { had obtained } \\
\text { specimens for viral } \\
\text { culture. Educational } \\
\text { intervention, while did } \\
\text { not set out to change } \\
\text { physician behaviour, did } \\
\text { have this effect. }\end{array}$ & $\begin{array}{l}\text { Levels } 1 \\
\text { and } 3\end{array}$ \\
\hline Bain 1984 & $\begin{array}{l}\text { Program } \\
\text { descrip- } \\
\text { tion } \\
\text { United } \\
\text { Kingdom }\end{array}$ & $\begin{array}{l}\text { To assess the } \\
\text { diagno- } \\
\text { sis/treatments for } \\
\text { acute earache in } \\
\text { children developed } \\
\text { by a trainee before } \\
\text { and after } 6 \text { months } \\
\text { with a trainer }\end{array}$ & $\begin{array}{l}24 \text { Trainers and their Trainees } \\
\text { were asked to examine the case } \\
\text { histories of } 5 \text { children with } 24 \\
\text { hours of ear ache }\end{array}$ & $\begin{array}{l}\text { Trainers and } \\
\text { trainees (does } \\
\text { not state level) }\end{array}$ & $\begin{array}{l}\text { Prescription rates } \\
\text { of different } \\
\text { medications }\end{array}$ & $\begin{array}{l}\text { Fall in trainees prescrib- } \\
\text { ing of antibiotics for } \\
\text { otitis media (although } \\
\text { not statistically signifi- } \\
\text { cant), but this was } \\
\text { correlated with an } \\
\text { increase in prescribing of } \\
\text { decongestant- } \\
\text { antihistamines }\end{array}$ & Level 2 \\
\hline $\begin{array}{l}\text { Dawson, } \\
\text { Bennett } \\
\text { and } \\
\text { Ongley, } \\
2010\end{array}$ & $\begin{array}{l}\text { Letter to } \\
\text { the editor } \\
\text { United } \\
\text { Kingdom }\end{array}$ & $\begin{array}{l}\text { To evaluate the use } \\
\text { of e-learning } \\
\text { modules on } \\
\text { antibiotic } \\
\text { prescribing }\end{array}$ & $\begin{array}{l}\text { A mandatory induction } \\
\text { module; a module on antibiotic } \\
\text { prescribing }\end{array}$ & $\begin{array}{l}\text { All staff, } \\
\text { including } \\
\text { residents and } \\
\text { medical } \\
\text { students }\end{array}$ & $\begin{array}{l}\text { Use of e-learner } \\
\text { package and effect } \\
\text { on on-site } \\
\text { training }\end{array}$ & $\begin{array}{l}\text { The modules have } \\
\text { enabled the junior } \\
\text { doctors to become } \\
\text { familiar with Trust } \\
\text { procedures and IPC and } \\
\text { antibiotic policies, and } \\
\text { have reduced the time } \\
\text { required for on-site } \\
\text { induction training }\end{array}$ & Level 2 \\
\hline $\begin{array}{l}\text { Faryna, } \\
\text { Wer- } \\
\text { gowske } \\
\text { and } \\
\text { Golden- } \\
\text { berg, } \\
1987\end{array}$ & $\begin{array}{l}\text { Research } \\
\text { United } \\
\text { States }\end{array}$ & $\begin{array}{l}\text { To understand the } \\
\text { impact of } \\
\text { therapeutic } \\
\text { guidelines on } \\
\text { outpatient } \\
\text { prescribing patterns } \\
\text { of internal medicine } \\
\text { residents }\end{array}$ & $\begin{array}{l}\text { A one-page set of treatment } \\
\text { guidelines was designed by } \\
\text { internal medicine staff and } \\
\text { placed on the desks of their } \\
\text { examining rooms. A pre and } \\
\text { post intervention survey was } \\
\text { collected }\end{array}$ & Residents & $\begin{array}{l}\text { Antibiotic choice } \\
\text { and appropriate- } \\
\text { ness }\end{array}$ & $\begin{array}{l}\text { Pre-intervention showed } \\
50 \% \text { of antibiotic choices } \\
\text { were inappropriate, but } \\
\text { there was no significant } \\
\text { difference in pre- and } \\
\text { post-intervention } \\
\text { antibiotic choices. The } \\
\text { more experienced a } \\
\text { resident, the less } \\
\text { appropriate the antibiot- }\end{array}$ & Level 2 \\
\hline
\end{tabular}




\begin{tabular}{|c|c|c|c|c|c|c|c|}
\hline $\begin{array}{l}\text { Author, } \\
\text { year }\end{array}$ & $\begin{array}{l}\text { Article } \\
\text { type and } \\
\text { location }\end{array}$ & $\begin{array}{l}\text { Purpose of } \\
\text { intervention }\end{array}$ & Intervention design & $\begin{array}{l}\text { Target } \\
\text { learner group }\end{array}$ & $\begin{array}{l}\text { Variables } \\
\text { of interest }\end{array}$ & Results and conclusions & $\begin{array}{l}\text { Kirkpatrick } \\
\text { evaluation } \\
\text { level }^{*}\end{array}$ \\
\hline
\end{tabular}

ics prescription pre-

intervention, but there

was no difference after

between experience

levels. The guidelines did

not result in a significant

decrease in proportion of

inappropriate antibiotic.

prescriptions. More

effective surveillance is

needed in the area of

outpatient antibiotic

prescribing by residents;

audits are a practical way

to monitor prescribing

behaviour

\begin{tabular}{|c|c|c|c|}
\hline $\begin{array}{l}\text { Feucht et } \\
\text { al, } 2003\end{array}$ & $\begin{array}{l}\text { Research } \\
\text { United } \\
\text { States }\end{array}$ & $\begin{array}{l}\text { To improve IV } \\
\text { vancomycin and } \\
\text { fluoroquinolone } \\
\text { prescribing } \\
\text { practices with } \\
\text { guidelines. (ie: } \\
\text { encourage early } \\
\text { discontinuation of } \\
\text { inappropriate use or } \\
\text { duplicative gram } \\
\text { negative coverage) }\end{array}$ & $\begin{array}{l}\text { Monthly or semi-monthly } \\
\text { conferences on antimicrobial } \\
\text { therapy and resistance, as well } \\
\text { as guidelines and current } \\
\text { hospital practices. Antibiotic } \\
\text { use monitoring by clinical } \\
\text { pharmacist with consultation if } \\
\text { use deemed inappropriate. } \\
\text { Reprints of the guidelines were } \\
\text { also placed in the medicine } \\
\text { physician conference rooms. }\end{array}$ \\
\hline
\end{tabular}

$\begin{array}{ll}\text { Residents and } & \text { Number of } \\ \text { staff } & \text { metrics including } \\ & \text { number of } \\ \text { inappropriate } & \text { prescriptions, } \\ & \text { length of course, } \\ \text { and number of } & \text { antibiotic courses } \\ & \text { overall }\end{array}$

The intervention

Level 2

decreases unnecessary

duplicative regimens,

number of courses

overall of some antibiot-

ics, courses over 5 days,

and inappropriate

prescribing. Appropriate

educational intervention

programs can alter

prescribing patterns in

residents, particularly in

early discontinuation of

inappropriate therapy

and altering prescribing

practices of fluoroquin-

olones.

\begin{tabular}{|c|c|c|c|c|c|c|c|}
\hline $\begin{array}{l}\text { Huang et } \\
\text { al, } 2013\end{array}$ & $\begin{array}{l}\text { Research } \\
\text { China }\end{array}$ & $\begin{array}{l}\text { Purpose of survey: } \\
\text { to get an overview } \\
\text { of the students' } \\
\text { understanding of } \\
\text { antibiotics, and to } \\
\text { compare the } \\
\text { medical students' } \\
\text { and non-medical } \\
\text { students' } \\
\text { knowledge, } \\
\text { attitude and } \\
\text { behaviour towards } \\
\text { antibiotic use }\end{array}$ & $\begin{array}{l}\text { Curriculum gives intro of } \\
\text { infectious diseases. Antibiotic } \\
\text { prescription is supervised by } \\
\text { clinicians during clinical } \\
\text { internship. Gave questionnaire } \\
\text { on: knowledge of antibiotics, } \\
\text { attitude towards antibiotic use, } \\
\text { perception of public education } \\
\text { and practice towards antibiotic } \\
\text { use. }\end{array}$ & $\begin{array}{l}\text { Medical } \\
\text { students }\end{array}$ & $\begin{array}{l}\text { Knowledge of } \\
\text { antibiotic use; } \\
\text { attitude and } \\
\text { public education } \\
\text { on usage of } \\
\text { antibiotics; } \\
\text { behaviour of } \\
\text { using antibiotics }\end{array}$ & $\begin{array}{l}\text { Medical school did } \\
\text { improve knowledge of } \\
\text { antibiotic use; majority } \\
\text { of students thought } \\
\text { antimicrobial resistance } \\
\text { was a problem in China } \\
\text { and results from } \\
\text { antibiotic abuse and } \\
\text { more public education is } \\
\text { necessary. Medical } \\
\text { students scored worse } \\
\text { than non-medical } \\
\text { students on behaviour } \\
\text { towards use of antibiot- } \\
\text { ics. Medical students got } \\
\text { better as they progressed } \\
\text { through their years } \\
\text { indicating that the } \\
\text { schooling improved their } \\
\text { knowledge }\end{array}$ & Level 2 \\
\hline $\begin{array}{l}\text { Ikai et al, } \\
2012\end{array}$ & $\begin{array}{l}\text { Research } \\
\text { Japan }\end{array}$ & $\begin{array}{l}\text { To understand the } \\
\text { effect of postgrad- } \\
\text { uate education on } \\
\text { physicians' } \\
\text { adherence to the } \\
\text { guidelines or on } \\
\text { patient outcomes. }\end{array}$ & $\begin{array}{l}\text { Systematic lectures and case- } \\
\text { based discussions. A hospital- } \\
\text { wide restricted formulary to } \\
\text { decrease carbapenem. Analysed } \\
\text { via chart review. }\end{array}$ & Residents & $\begin{array}{l}\text { Appropriateness } \\
\text { of antibiotics } \\
\text { prescribed, } \\
\text { reasons for } \\
\text { inappropriate use }\end{array}$ & $\begin{array}{l}\text { More frequent blood, } \\
\text { sputum cultures and } \\
\text { gram stains; less frequent } \\
\text { use of broad spectrum } \\
\text { antibiotics as initial } \\
\text { empiric therapy; median } \\
\text { length of stay was shorter } \\
\text { after intervention; de- } \\
\text { escalation from parental } \\
\text { to oral was not signifi- }\end{array}$ & Level 2 \\
\hline
\end{tabular}


Silverberg et al. Antimicrobial stewardship training in medical education

\begin{tabular}{|c|c|c|c|c|c|c|c|}
\hline $\begin{array}{l}\text { Author, } \\
\text { year }\end{array}$ & $\begin{array}{l}\text { Article } \\
\text { type and } \\
\text { location }\end{array}$ & $\begin{array}{l}\text { Purpose of } \\
\text { intervention }\end{array}$ & Intervention design & $\begin{array}{l}\text { Target } \\
\text { learner group }\end{array}$ & $\begin{array}{l}\text { Variables } \\
\text { of interest }\end{array}$ & Results and conclusions & $\begin{array}{l}\text { Kirkpatrick } \\
\text { evaluation } \\
\text { level }^{*}\end{array}$ \\
\hline & & & & & & $\begin{array}{l}\text { cant; more cases were } \\
\text { treated with oral abs. }\end{array}$ & \\
\hline $\begin{array}{l}\text { Pisano et } \\
\text { al. } 2016\end{array}$ & $\begin{array}{l}\text { Research } \\
\text { United } \\
\text { States }\end{array}$ & $\begin{array}{l}\text { Study aims to } \\
\text { augment reach \& } \\
\text { boost antimicrobi- } \\
\text { al stewardship } \\
\text { through utilization } \\
\text { of social media }\end{array}$ & $\begin{array}{l}\text { Pre- and post- intervention } \\
\text { surveys - including } 20 \\
\text { questions on antibiotics \& } \\
\text { infectious diseases and } \\
\text { awareness of ASP initiatives, } \\
\text { social media usage \& attitudes } \\
\text { surrounding antimicrobial } \\
\text { resistance }\end{array}$ & $\begin{array}{l}55 \text { internal } \\
\text { medicine } \\
\text { residents }\end{array}$ & $\begin{array}{l}\text { Pre- and post- } \\
\text { intervention } \\
\text { surveys after the } \\
\text { ASP social media } \\
\text { intervention } \\
\text { (which included } \\
\text { trivia questions } \\
\text { on antimicrobial } \\
\text { resistance/ } \\
\text { antibiotics } \\
\text { prescription, links } \\
\text { to teaching } \\
\text { articles or internal } \\
\text { content on ASP } \\
\text { website - using } \\
\text { Twitter \& } \\
\text { Facebook) }\end{array}$ & $\begin{array}{l}\text { Study concluded that } \\
\text { social media proved to be } \\
\text { a valuable tool to } \\
\text { reinforce ASP initiatives } \\
\text { and education, while } \\
\text { encouraging the use of } \\
\text { ASP so as to promote } \\
\text { Antimicrobial mindful- } \\
\text { ness in clinical practice. } \\
\text { antibiotics knowledge } \\
\text { scores increased } \\
\text { following the social } \\
\text { media education } \\
\text { intervention, and access } \\
\text { to ASP increased from } \\
70 \% \text { - } 94 \% \text {. Further, } \\
\text { more IMRs indicated } \\
\text { using the ASP clinical } \\
\text { pathways more frequent- } \\
\text { ly post- intervention }\end{array}$ & Level 2 \\
\hline $\begin{array}{l}\text { Rawson et } \\
\text { al. } 2016\end{array}$ & $\begin{array}{l}\text { Research } \\
\text { United } \\
\text { Kingdom }\end{array}$ & $\begin{array}{l}\text { To investigate the } \\
\text { coverage of AMS } \\
\text { across UK clinical } \\
\text { postgrad curricula } \\
\text { \& assess quality of } \\
\text { education }\end{array}$ & $\begin{array}{l}\text { Cross-sectional analysis \& } \\
\text { quality assessment }\end{array}$ & $\begin{array}{l}\text { Postgraduate } \\
\text { medical } \\
\text { students ( } 37 \\
\text { specialties; } \\
\text { inter-specialty } \\
\text { analysis } \\
\text { performed) }\end{array}$ & $\begin{array}{l}37 \text { Specialties } \\
\text { assessed: topics \& } \\
\text { individual } \\
\text { learning points } \\
\text { relating to } \\
\text { antimicrobial } \\
\text { stewardship \& } \\
\text { resistance were } \\
\text { extracted for each } \\
\text { specialty, and } \\
\text { these were then } \\
\text { quality assessed, } \\
\text { followed by inter- } \\
\text { specialty analysis }\end{array}$ & $\begin{array}{l}\text { Overall coverage of } \\
\text { antimicrobial steward- } \\
\text { ship \& resistance is } \\
\text { relatively poor across the } \\
\text { majority of UK post- } \\
\text { graduate clinical training } \\
\text { curricula, with little } \\
\text { depth of learning } \\
\text { enacted. Of the } 37 \\
\text { specialties assessed, } 2,318 \\
\text { topics \& } 42,527 \text { learning } \\
\text { points were identified - } \\
\text { of these, } 0.3 \% \text { topics \& } \\
\text { 0.4\% learning points } \\
\text { were related to antimi- } \\
\text { crobial steward- } \\
\text { ship/resistance. In } \\
\text { contrast, primary care, } \\
\text { which is responsible for } \\
\text { the highest proportion of } \\
\text { antimicrobial usage, only } \\
\text { had } 0.15 \% \text { antimicrobial } \\
\text { stewardship/resistance } \\
\text { learning points. On } \\
\text { quality assessment, } 60 \% \\
\text { of learning points } \\
\text { required knowledge only, } \\
\text { with no demonstration } \\
\text { of behaviour in clinical } \\
\text { practice. }\end{array}$ & Level 2 \\
\hline $\begin{array}{l}\text { Zamin, } \\
\text { Pitre and } \\
\text { Conly, } \\
1997\end{array}$ & $\begin{array}{l}\text { Research } \\
\text { Canada }\end{array}$ & $\begin{array}{l}\text { To assess the effect } \\
\text { of introducing a } \\
\text { route conversion } \\
\text { program on the } \\
\text { prescribing of } \\
\text { antimicrobials for } \\
\text { the treatment of } \\
\text { respiratory tract } \\
\text { infections and } \\
\text { skin/soft tissue } \\
\text { infections }\end{array}$ & $\begin{array}{l}\text { General medicine wards at a } \\
\text { tertiary care health centre had a } \\
\text { route conversion program had } \\
\text { the insight of infectious disease } \\
\text { physicians and microbiologists, } \\
\text { as well as pharmacists }\end{array}$ & $\begin{array}{l}\text { Medical } \\
\text { students post- } \\
\text { graduate } \\
\text { trainees, staff }\end{array}$ & $\begin{array}{l}\text { Clinical and } \\
\text { laboratory } \\
\text { parameters } \\
\text { related to the } \\
\text { status of the } \\
\text { infection } \\
\text { compared with } \\
\text { course of therapy; } \\
\text { patient's ability to } \\
\text { meet the criteria } \\
\text { established in the }\end{array}$ & $\begin{array}{l}\text { Even after program } \\
\text { introduction, the } \\
\text { number of days that IV } \\
\text { therapy was continued, } \\
\text { despite the appropriate- } \\
\text { ness of oral therapy, was } \\
\text { reduced. The program } \\
\text { had a positive influence } \\
\text { on antimicrobial } \\
\text { prescribing behaviour in } \\
\text { the population studied. }\end{array}$ & Level 2 \\
\hline
\end{tabular}




\begin{tabular}{|c|c|c|c|c|c|c|c|}
\hline $\begin{array}{l}\text { Author, } \\
\text { year }\end{array}$ & $\begin{array}{l}\text { Article } \\
\text { type and } \\
\text { location }\end{array}$ & $\begin{array}{l}\text { Purpose of } \\
\text { intervention }\end{array}$ & Intervention design & $\begin{array}{l}\text { Target } \\
\text { learner group }\end{array}$ & $\begin{array}{l}\text { Variables } \\
\text { of interest }\end{array}$ & Results and conclusions & $\begin{array}{l}\text { Kirkpatrick } \\
\text { evaluation } \\
\text { level }^{*}\end{array}$ \\
\hline & & & & & $\begin{array}{l}\text { guidelines; } \\
\text { number of days of } \\
\text { IV therapy }\end{array}$ & & \\
\hline $\begin{array}{l}\text { De } \\
\text { Souza V } \\
\text { et al, } 2006\end{array}$ & $\begin{array}{l}\text { Research } \\
\text { Ireland }\end{array}$ & $\begin{array}{l}\text { Medical school } \\
\text { curriculum: to teach } \\
\text { students proper } \\
\text { antimicrobial } \\
\text { prescribing. Overall: } \\
\text { to evaluate factors } \\
\text { that influence } \\
\text { prescribing by non- } \\
\text { consultant hospital } \\
\text { doctors }\end{array}$ & $\begin{array}{l}\text { Curriculum design / influences } \\
\text { on young doctors that is } \\
\text { discussed: the practices of } \\
\text { senior colleagues on their } \\
\text { teams; personal experience } \\
\text { later in their career; under- } \\
\text { graduate lectures; hospital } \\
\text { guidelines }\end{array}$ & $\begin{array}{l}\text { Medical } \\
\text { students and } \\
\text { postgraduate } \\
\text { trainees }\end{array}$ & $\begin{array}{l}\text { Processing and } \\
\text { mastery of } \\
\text { medical microbi- } \\
\text { ology learning } \\
\text { content, enjoy- } \\
\text { ment derived } \\
\text { from intervention, } \\
\text { Qualitative } \\
\text { evidence of } \\
\text { positive affect } \\
\text { generated by } \\
\text { intervention }\end{array}$ & $\begin{array}{l}\text { While undergraduate } \\
\text { training in medical } \\
\text { microbiology provided } \\
\text { information on infec- } \\
\text { tions, it left interns } \\
\text { insufficiently trained to } \\
\text { make autonomous } \\
\text { antimicrobial prescribing } \\
\text { decisions. Formal } \\
\text { undergraduate education } \\
\text { on antimicrobial agents, } \\
\text { rationale for antimicro- } \\
\text { bial use, existing hospital } \\
\text { guidelines and concerns } \\
\text { about emerging } \\
\text { resistance appear to be } \\
\text { minor influences. Those } \\
\text { trained in low income } \\
\text { countries had greater } \\
\text { knowledge and autono- } \\
\text { my in their prescribing }\end{array}$ & Level 3 \\
\hline $\begin{array}{l}\text { Irfan et al. } \\
2015\end{array}$ & $\begin{array}{l}\text { Research } \\
\text { Canada }\end{array}$ & $\begin{array}{l}\text { Identify risk } \\
\text { factors for } \\
\text { unnecessary } \\
\text { prescription and to } \\
\text { assess impact of } \\
\text { educational } \\
\text { intervention } \\
\text { focused on } \\
\text { prescription of } \\
\text { antibiotics }\end{array}$ & $\begin{array}{l}\text { Quasi-experimental study, with } \\
\text { a control group }\end{array}$ & $\begin{array}{l}\text { Medical } \\
\text { residents }\end{array}$ & $\begin{array}{l}\text { Study compared } \\
\text { baseline period of } \\
\text { patients with } \\
\text { positive urine } \\
\text { cultures to } \\
\text { educational } \\
\text { intervention } \\
\text { period to compare } \\
\text { appropriate } \\
\text { antibiotic } \\
\text { prescriptions }\end{array}$ & $\begin{array}{l}\text { Educational intervention } \\
\text { was effective in the } \\
\text { reduction of unnecessary } \\
\text { antibiotic use - } 52 \% \text { of } \\
\text { control interventions } \\
\text { were inappropriately } \\
\text { prescribed compared to } \\
8 \% \text { following interven- } \\
\text { tion }\end{array}$ & Level 3 \\
\hline $\begin{array}{l}\text { Lee et al, } \\
2014\end{array}$ & $\begin{array}{l}\text { Research } \\
\text { Canada }\end{array}$ & $\begin{array}{l}\text { To optimize } \\
\text { antibiotic use } \\
\text { through trainee- } \\
\text { led time-outs }\end{array}$ & $\begin{array}{l}\text { While receiving monthly } \\
\text { education on antimicrobial } \\
\text { stewardship, residents adjusted } \\
\text { patients' antibiotic therapy } \\
\text { through twice-weekly time-out } \\
\text { audits using a structured } \\
\text { electronic checklist }\end{array}$ & $\begin{array}{l}\text { Residents } \\
\text { (medical } \\
\text { students were } \\
\text { on the team } \\
\text { during the } \\
\text { audit, but it is } \\
\text { unclear } \\
\text { whether they } \\
\text { participated) }\end{array}$ & $\begin{array}{l}\text { Cost savings, } \\
\text { comfort with } \\
\text { antibiotic } \\
\text { prescribing, } \\
\text { patient prescrip- } \\
\text { tion rates }\end{array}$ & $\begin{array}{l}\$ 70,000 \text { savings } \\
\text { associated with } 1 \text { hour of } \\
\text { faculty time and } 8 \text { hours } \\
\text { of resident time. } 80 \% \text { of } \\
\text { residents adhered to the } \\
\text { auditing program and } \\
\text { believed it improved } \\
\text { their comfort with } \\
\text { antibiotics and provided } \\
\text { clinical value. } 1 \text { in } 7 \\
\text { patients had their } \\
\text { antibiotics changed after } \\
\text { the first audit. Rates of C } \\
\text { diff decreased. No } \\
\text { mention of medical } \\
\text { students directly }\end{array}$ & Level 3 \\
\hline $\begin{array}{l}\text { Légaré et } \\
\text { al, } 2011\end{array}$ & $\begin{array}{l}\text { Research } \\
\text { Protocol } \\
\text { Canada }\end{array}$ & $\begin{array}{l}\text { To improve the use } \\
\text { of antibiotics in } \\
\text { family medicine } \\
\text { treatment of acute } \\
\text { respiratory } \\
\text { infections }\end{array}$ & $\begin{array}{l}\text { Web-based tutorial followed by } \\
\text { interactive workshops; } \\
\text { addressed clinical decision- } \\
\text { making process regarding } \\
\text { antibiotics treatment }\end{array}$ & $\begin{array}{l}\text { Residents and } \\
\text { staff }\end{array}$ & $\begin{array}{l}\text { Proportion of } \\
\text { patients reporting } \\
\text { a decision to use } \\
\text { antibiotics } \\
\text { immediately }\end{array}$ & N/A & Level 3 \\
\hline $\begin{array}{l}\text { Main and } \\
\text { Koerner, } \\
2012\end{array}$ & $\begin{array}{l}\text { Letter to } \\
\text { the editor } \\
\text { United } \\
\text { Kingdom } \\
\text { and }\end{array}$ & $\begin{array}{l}\text { To reduce levels of } \\
\text { antimicrobial } \\
\text { resistance }\end{array}$ & $\begin{array}{l}\text { Audit; using a restricted group } \\
\text { of antibiotics }\end{array}$ & Residents & $\begin{array}{l}\text { Incidence of } \\
\text { multi-drug- } \\
\text { resistant microbes }\end{array}$ & $\begin{array}{l}\text { Reduced incidence of } \\
\text { multi-drug-resistant } \\
\text { microbes; not enough } \\
\text { evidence to expand }\end{array}$ & Level 3 \\
\hline
\end{tabular}


Silverberg et al. Antimicrobial stewardship training in medical education

\begin{tabular}{|c|c|c|c|c|c|c|c|}
\hline $\begin{array}{l}\text { Author, } \\
\text { year }\end{array}$ & $\begin{array}{l}\text { Article } \\
\text { type and } \\
\text { location }\end{array}$ & $\begin{array}{l}\text { Purpose of } \\
\text { intervention }\end{array}$ & Intervention design & $\begin{array}{l}\text { Target } \\
\text { learner group }\end{array}$ & $\begin{array}{l}\text { Variables } \\
\text { of interest }\end{array}$ & Results and conclusions & $\begin{array}{l}\text { Kirkpatrick } \\
\text { evaluation } \\
\text { level }^{*}\end{array}$ \\
\hline & \multicolumn{7}{|l|}{ Europe } \\
\hline $\begin{array}{l}\text { McLellan } \\
\text { et al. } 2016\end{array}$ & $\begin{array}{l}\text { Research } \\
\text { United } \\
\text { Kingdom }\end{array}$ & $\begin{array}{l}\text { Investigate } \\
\text { whether \& how } \\
\text { structured } \\
\text { feedback sessions } \\
\text { can increase rates } \\
\text { of appropriate } \\
\text { antimicrobial } \\
\text { prescribing by } \\
\text { junior MDs }\end{array}$ & $\begin{array}{l}\text { Participants randomized to } \\
\text { intervention (pharmacist-led } \\
\text { feedback sessions) and control } \\
\text { (routine practice) } 2 \text { days/week } \\
\text { for } 6 \text { months, mean normalized } \\
\text { prescribing rates \& qualitative } \\
\text { interviews }\end{array}$ & $\begin{array}{l}\text { Junior doctors } \\
\text { (post graduate } \\
\text { residents) in } \\
\text { their first year } \\
\text { of training }\end{array}$ & $\begin{array}{l}\text { Researchers } \\
\text { assessed normal- } \\
\text { ized rates of } \\
\text { prescription. } \\
\text { Further, thematic } \\
\text { analysis of } \\
\text { qualitative } \\
\text { interviews was } \\
\text { completed to gain } \\
\text { insight into the } \\
\text { feedback } \\
\text { workshops }\end{array}$ & $\begin{array}{l}\text { Study found that the } \\
\text { Pharmacist-led feedback } \\
\text { intervention augmented } \\
\text { appropriate prescription } \\
\text { patterns in junior } \\
\text { doctors, by acting as a } \\
\text { positive stimulus within } \\
\text { a complex network of } \\
\text { behavioural influences. } \\
\text { The authors conclude } \\
\text { that prescribing } \\
\text { behaviour is adaptable } \\
\text { and can influence best } \\
\text { practice guidelines by } \\
\text { reducing suboptimal } \\
\text { antimicrobial prescribing }\end{array}$ & Level 3 \\
\hline $\begin{array}{l}\text { Zwar, } \\
\text { Gordon } \\
\text { and } \\
\text { Sanson- } \\
\text { Fisher, } \\
1995\end{array}$ & $\begin{array}{l}\text { Research } \\
\text { Australia }\end{array}$ & $\begin{array}{l}\text { To improve } \\
\text { rational prescrib- } \\
\text { ing of antibiotics } \\
\text { and benzodiaze- } \\
\text { pines }\end{array}$ & $\begin{array}{l}\text { Randomized control trial } \\
\text { evaluating a seminar on } \\
\text { rational prescribing focusing } \\
\text { on skills and knowledge. } \\
\text { Included: information } \\
\text { including reference to } \\
\text { guidelines, process skills and } \\
\text { feedback on performance. } \\
\text { Group discussion then held } \\
\text { and feedback on performance } \\
\text { given. }\end{array}$ & Residents & $\begin{array}{l}\text { Rate of antibiotic } \\
\text { prescription for } \\
\text { all conditions; } \\
\text { prescribing of } \\
\text { antibiotics for } \\
\text { URTI, choice of } \\
\text { antibiotics for } \\
\text { conditions } \\
\text { including } \\
\text { tonsillitis, } \\
\text { sinusitis, acute } \\
\text { otitis media, etc. } \\
\text { Benzodiazepine } \\
\text { prescription for } \\
\text { all conditions }\end{array}$ & $\begin{array}{l}\text { Group educational } \\
\text { approaches to influence } \\
\text { prescribing can be } \\
\text { effective. Decrease in } \\
\text { antibiotic prescribing, } \\
\text { but often non-significant } \\
\text { decreases in intervention } \\
\text { group and increases in } \\
\text { control. Further research } \\
\text { is needed to assess } \\
\text { whether prescribing } \\
\text { behaviour is affected by } \\
\text { feedback, guidelines, } \\
\text { reminders, etc. }\end{array}$ & Level 3 \\
\hline $\begin{array}{l}\text { Zwar et } \\
\text { al, } 1999\end{array}$ & $\begin{array}{l}\text { Research } \\
\text { Australia }\end{array}$ & $\begin{array}{l}\text { To examine } \\
\text { effectiveness of an } \\
\text { intervention to } \\
\text { reduce antibiotic } \\
\text { prescribing in GP } \\
\text { trainees for } \\
\text { undifferentiated } \\
\text { upper RTI and } \\
\text { improve antibiotic } \\
\text { choice }\end{array}$ & $\begin{array}{l}\text { Individual prescriber feedback, } \\
\text { followed by further resources } \\
\text { and further visits. Prescriber } \\
\text { feedback and educational } \\
\text { outreach also given. }\end{array}$ & Residents & $\begin{array}{l}\text { Diagnostic } \\
\text { behaviour }\end{array}$ & $\begin{array}{l}\text { Antibiotic prescribing by } \\
\text { the intervention group } \\
\text { declined, while the } \\
\text { control group increased. } \\
\text { Prescribing in agreement } \\
\text { with accepted guidelines } \\
\text { increased in the } \\
\text { intervention group, but } \\
\text { decreased in the control } \\
\text { group. Prescriber } \\
\text { feedback and manage- } \\
\text { ment guidelines } \\
\text { influenced antibiotic } \\
\text { prescribing and choice of } \\
\text { antibiotic. }\end{array}$ & Level 3 \\
\hline $\begin{array}{l}\text { Tham- } \\
\text { likitkul et } \\
\text { al, } 1998\end{array}$ & $\begin{array}{l}\text { Research } \\
\text { Thailand }\end{array}$ & $\begin{array}{l}\text { To reduce } \\
\text { inappropriate } \\
\text { prescribing in a } \\
\text { hospital setting }\end{array}$ & $\begin{array}{l}\text { Information feedback and } \\
\text { antibiotic guidelines through } \\
\text { information sessions. Data } \\
\text { from patients prescribed } \\
\text { antibiotics was collected before } \\
\text { and after educational interven- } \\
\text { tion }\end{array}$ & $\begin{array}{l}\text { Residents, } \\
\text { staff, and final } \\
\text { year medical } \\
\text { students }\end{array}$ & $\begin{array}{l}\text { Frequency of } \\
\text { antibiotic use and } \\
\text { their cost pre-and } \\
\text { post-intervention }\end{array}$ & $\begin{array}{l}22 \% \text { reduction in } \\
\text { antibiotics use in in- } \\
\text { patients; } 23 \% \text { in } \\
\text { outpatients. Most } \\
\text { antibiotics are prescribed } \\
\text { by residents, GPs in } \\
\text { outpatient clinics and } \\
\text { final year medical } \\
\text { students. The education- } \\
\text { al program was effective. }\end{array}$ & $\begin{array}{l}\text { Level } 3 \text { and } \\
4\end{array}$ \\
\hline
\end{tabular}

"Kirkpatrick Levels of Evaluation: (1) reaction (satisfaction or happiness; what participants thought of the educational intervention), (2) learning (change in attitude and/or knowledge or skills gained assessed by test or demonstration), (3) behaviour (transfer of attitude, knowledge and/or skills to workplace or clinical setting), and (4) results (patient care affected or societal impact due to participation in the educational intervention evaluated) ${ }^{32}$ 